\title{
First records and two new species of sipunculans (Sipuncula) from the Southern Mexican Pacific
}

\author{
Itzahí SILVA-MORALES ${ }^{1, *} \&$ Julio D. GÓMEZ-VÁSQUEZ ${ }^{2}$ \\ ${ }^{1}$ División de Posgrado, El Colegio de la Frontera Sur, Unidad Chetumal, Quintana Roo, Mexico. \\ ${ }^{2}$ Laboratorio de Sistemática de Invertebrados Marinos (LABSIM), Universidad del Mar campus \\ Puerto Ángel, Ciudad Universitaria, Puerto Ángel, Pochutla, Oaxaca 70902, Mexico. \\ *Corresponding author: itzahi_marley.gwn@hotmail.com \\ ${ }^{2}$ Email: gomezvjuliod@gmail.com \\ 1 (1) https://orcid.org/0000-0002-0796-0667 \\ ${ }^{1}$ urn:lsid:zoobank.org:author:ADA5A4BD-EB4E-47E3-A6A7-D3E1FDA64ED3 \\ ${ }^{2}$ urn:1sid:zoobank.org:author:BD3A3DE1-21F5-4B54-A707-361BE8E90DB9
}

\begin{abstract}
Sipunculans are a poorly studied group in the Tropical Eastern Pacific. For the Southern Mexican Pacific (SMP) there is only one record of a sipunculan species. The main objective of this work was to determine the species composition of the phylum Sipuncula present in the SMP. The study area covered three Mexican states: Guerrero, Oaxaca and Chiapas; specimens from 28 localities were examined from both intertidal and subtidal zones. A total of 551 specimens were reviewed, from which 11 species were identified. Five of them have previously been recorded in the Tropical Eastern Pacific (TEP): Apionsoma (A.) hespera comb. nov., A. (Edmondsius) pectinatum, Aspidosiphon (A.) elegans, Phascolosoma (P.) puntarenae and Themiste (T.) hennahi; four species are similar to nominal species: Sipunculus (S.) cf. polymyotus, Siphonosoma cf. vastum, Siphonosoma cf. cumanense and Phascolosoma (P.) cf. perlucens; and two new species are described: Aspidosiphon (Paraspidosiphon) cutleri sp. nov. and Aspidosiphon (Paraspidosiphon) pastori sp. nov. A checklist and an identification key for all sipunculan species from the TEP are presented. The checklist includes 53 taxa, 25 of which are questionable records. This work generated 11 new records of sipunculans in the SMP and five new records in the TEP.
\end{abstract}

Keywords. Aspidosiphon, Chiapas, Guerrero, Oaxaca, Phascolosoma.

Silva-Morales I. \& Gómez-Vásquez J.D. 2021. First records and two new species of sipunculans (Sipuncula) from the Southern Mexican Pacific. European Journal of Taxonomy 740: 77-117.

https://doi.org/10.5852/ejt.2021.740.1283

\section{Introduction}

Sipunculans are a small group of unsegmented vermiform, coelomate and protostome marine worms (Cutler 1994; Murina 1984) and are considered close to or even within the annelid group (Staton 2003; 
Struck et al. 2007; Dordel et al. 2010). They are commonly known as 'peanut worms' or 'star worms' (Schulze et al. 2019), and they have a body divided in a retractable introvert and trunk. Sipuncula earlier comprised 320 species (sensu Stephen \& Edmonds 1972); however, the revisions of Cutler \& Cutler (Cutler 1979; Cutler \& Cutler 1982, 1983, 1985a, 1985b, 1986, 1987, 1988, 1989, 1990) reduced the number to 150 valid species (Cutler 1994). Traditionally, the phylum has included two classes, four orders, six families and 17 genera (Cutler \& Gibbs 1985; Gibbs \& Cutler 1987) but Kawauchi et al. (2012) proposed a new classification based on a molecular phylogenetic analysis. Subsequently, Lemer et al. (2015) corroborated these results. The new classification now includes six families and 16 genera, leaving out the classes and orders.

In the Tropical Eastern Pacific (TEP), most sipunculan species are reported from northwestern Mexico and Costa Rica, as well as a few other few localities from Colombia, Panama and the Galapagos Islands (Gray 1828; Grube 1858; Keferstein 1866, 1867; Fischer 1895; Chamberlin 1920; Steinbeck \& Ricketts 1941; Fisher 1952; Cutler \& Cutler 1980; Salazar-Vallejo 1983; Fonseca \& Cortés 1988; Cutler et al. 1992; Dean 2001; Cantera et al. 2003; Fonseca et al. 2005; Spongberg 2006; Yupanqui et al. 2007; Melwani \& Kim 2008; Dean et al. 2010; Hermoso-Salazar et al. 2013; Morales-Zárate et al. 2016). Also, no identification key or updated list of the sipunculans from TEP exist. The presence of this group in the Southern Mexican Pacific (SMP) is completely unknown (Bastida-Zavala et al. 2013); a single record of one new species in the SMP was made by Silva-Morales et al. (2019). Therefore, the main objective of this work was to determine the composition of species of the phylum Sipuncula present in the study area.

\section{Material and methods}

The revised specimens are from the Laboratorio de Sistemática de Invertebrados Marinos (LABSIM), Universidad del Mar, campus Puerto Ángel, Oaxaca, Mexico. The totality of specimens is derived from 28 localities in three coastal Mexican states: Guerrero, Oaxaca and Chiapas (Table 1). Most of the material is from intertidal and subtidal zones and some was collected during free diving on different substrates such as sand and rock, mainly coralline rocks. Collected specimens were fixed in $10 \%$ formalin and preserved in $70 \%$ ethanol. To identify the species, the identification keys of Cutler (1994) and Fisher (1952) were used. Internal and external anatomy was observed and described using a Zeiss stereo microscope; to examine the hooks and papillae, semi-permanent slides were prepared and visualized in a Zeiss compound microscope. The specimens were deposited in the Sipunculan Section of the Scientific Collection with the accession number OAX-CC-249-11 of the Laboratorio de Sistemática de Invertebrados Marinos, Universidad del Mar (UMAR), campus Puerto Ángel, Oaxaca, Mexico. Additional specimens were examined from the Polychaeta Collection of the Laboratorio de Poliquetos (ECOSUR), Chetumal, Quintana Roo, Mexico with the number QNR.IN.021.0497. The checklist and identification keys were assembled following an exhaustive review of the literature.

\section{Collector abbreviations}

$$
\begin{aligned}
\text { BMD } & =\text { Betzabé Berenice Moreno Dávila } \\
\text { DC } & =\text { Don Cadien } \\
\text { FRE } & =\text { Fernando Ruíz Escobar } \\
\text { GGG } & =\text { Gerardo Góngora-Garza } \\
\text { ILA } & =\text { Ildefonso "Mikel" Liñero-Arana } \\
\text { ISM } & =\text { Itzahí Silva-Morales } \\
\text { JDG } & =\text { Jesús Ángel de León-González } \\
\text { JGV } & =\text { Julio Daniel Gómez-Vásquez } \\
\text { JWC } & =\text { John W. Chapman } \\
\text { KLT } & =\text { Karina Marisol Lugo Trejo }
\end{aligned}
$$


SILVA-MORALES I. \& GÓMEZ-VÁSQUEZ J.D., Sipunculans from the Southern Mexican Pacific

Table 1. Geographic coordinates of localities. All localities are in Mexico.

\begin{tabular}{|c|c|}
\hline Locality & Geographic coordinates \\
\hline Coral Beach, Ixtapa Island, Guerrero & $17^{\circ} 40^{\prime} 37.0^{\prime \prime} \mathrm{N}, 101^{\circ} 39^{\prime} 20.2^{\prime \prime} \mathrm{W}$ \\
\hline Barra de Potosí, Guerrero & $17^{\circ} 32^{\prime} 19.6^{\prime \prime} \mathrm{N}, 101^{\circ} 26^{\prime} 36.7^{\prime \prime} \mathrm{W}$ \\
\hline La Quebrada, Acapulco, Guerrero & $16^{\circ} 50^{\prime} 44.2^{\prime \prime} \mathrm{N}, 99^{\circ} 54^{\prime} 54.8^{\prime \prime} \mathrm{W}$ \\
\hline Manzanillo Beach, Guerreo & $16^{\circ} 50^{\prime} 31.4^{\prime \prime} \mathrm{N}, 99^{\circ} 54^{\prime} 38.4^{\prime \prime} \mathrm{W}$ \\
\hline Roqueta Island, Guerrero & $16^{\circ} 49^{\prime} 19.8^{\prime \prime} \mathrm{N}, 99^{\circ} 54^{\prime} 17.6^{\prime \prime} \mathrm{W}$ \\
\hline Las Peñitas Beach, Marquelia, Guerrero & $16^{\circ} 33^{\prime} 16.2^{\prime \prime} \mathrm{N}, 98^{\circ} 46^{\prime} 21.7^{\prime \prime} \mathrm{W}$ \\
\hline Punta Maldonado Beach, Guerrero & $16^{\circ} 19^{\prime} 39.2^{\prime \prime} \mathrm{N}, 98^{\circ} 34^{\prime} 15.2^{\prime \prime} \mathrm{W}$ \\
\hline Chacahua, Oaxaca & $15^{\circ} 58^{\prime} 07.4^{\prime \prime} \mathrm{N}, 97^{\circ} 32^{\prime} 09.7^{\prime \prime} \mathrm{W}$ \\
\hline Cerro Hermoso Beach, Chacahua, Oaxaca & $15^{\circ} 58^{\prime} 08.1^{\prime \prime} \mathrm{N}, 97^{\circ} 32^{\prime} 06.6^{\prime \prime} \mathrm{W}$ \\
\hline Puerto Escondido, Oaxaca & $15^{\circ} 51^{\prime} 34.7^{\prime \prime} \mathrm{N}, 97^{\circ} 03^{\prime} 50.8^{\prime \prime} \mathrm{W}$ \\
\hline Santa Cruz Beach, Huatulco, Oaxaca & $15^{\circ} 45^{\prime} 10.7^{\prime \prime} \mathrm{N}, 96^{\circ} 07^{\prime} 49.7^{\prime \prime} \mathrm{W}$ \\
\hline La Montosa Island, Huatulco, Oaxaca & $15^{\circ} 45^{\prime} 57.2^{\prime \prime} \mathrm{N}, 96^{\circ} 05^{\prime} 03.4^{\prime \prime} \mathrm{W}$ \\
\hline Conejos Bay, Huatulco, Oaxaca & $15^{\circ} 46^{\prime} 44.6^{\prime \prime} \mathrm{N}, 9^{\circ} 03^{\prime} 51.7^{\prime \prime} \mathrm{W}$ \\
\hline La Entrega Beach, Huatulco, Oaxaca & $15^{\circ} 44^{\prime} 37.1^{\prime \prime} \mathrm{N}, 96^{\circ} 07^{\prime} 41.8^{\prime \prime} \mathrm{W}$ \\
\hline Violín Beach, Huatulco, Oaxaca & $15^{\circ} 44^{\prime} 24.4^{\prime \prime} \mathrm{N}, 96^{\circ} 07^{\prime} 38.3^{\prime \prime} \mathrm{W}$ \\
\hline Agua Blanca Beach, Oaxaca & $15^{\circ} 43^{\prime} 58.6^{\prime \prime} \mathrm{N}, 96^{\circ} 48^{\prime} 38.6^{\prime \prime} \mathrm{W}$ \\
\hline Jicaral Beach, Chachacual Bay, Oaxaca & $15^{\circ} 42^{\prime} 39.1^{\prime \prime} \mathrm{N}, 96^{\circ} 12^{\prime} 11.1^{\prime \prime} \mathrm{W}$ \\
\hline Salchi Beach, Huatulco, Oaxaca & $15^{\circ} 41^{\prime} 22.6^{\prime \prime} \mathrm{N}, 96^{\circ} 20^{\prime} 59.9^{\prime \prime} \mathrm{W}$ \\
\hline San Agustin Bay, Huatulco, Oaxaca & $15^{\circ} 41^{\prime} 21.1^{\prime \prime} \mathrm{N}, 9^{\circ} 14^{\prime} 11.1^{\prime \prime} \mathrm{W}$ \\
\hline La Tijera Beach, Puerto Ángel, Oaxaca & $15^{\circ} 41^{\prime} 15.5^{\prime \prime} \mathrm{N}, 96^{\circ} 26^{\prime} 33.5^{\prime \prime} \mathrm{W}$ \\
\hline Boquilla Beach, Puerto Ángel, Oaxaca & $15^{\circ} 40^{\prime} 58.5^{\prime \prime} \mathrm{N}, 96^{\circ} 27^{\prime} 54.5^{\prime \prime} \mathrm{W}$ \\
\hline Estacahuite Beach, Puerto Ángel, Oaxaca & $15^{\circ} 40^{\prime} 05.2^{\prime \prime} \mathrm{N}, 96^{\circ} 28^{\prime} 53.5^{\prime \prime} \mathrm{W}$ \\
\hline Playa del Amor, Zipolite, Oaxaca & $15^{\circ} 39^{\prime} 36.0^{\prime \prime} \mathrm{N}, 96^{\circ} 30^{\prime} 35.3^{\prime \prime} \mathrm{W}$ \\
\hline Panteón Beach, Puerto Ángel, Oaxaca & $15^{\circ} 39^{\prime} 50.8^{\prime \prime} \mathrm{N}, 96^{\circ} 29^{\prime} 42.4^{\prime \prime} \mathrm{W}$ \\
\hline Puerto Ángel Bay, Oaxaca & $15^{\circ} 39^{\prime} 56.3^{\prime \prime} \mathrm{N}, 96^{\circ} 29^{\prime} 29.0^{\prime \prime} \mathrm{W}$ \\
\hline Camarón Beach, Puerto Ángel, Oaxaca & $15^{\circ} 39^{\prime} 45.3^{\prime \prime} \mathrm{N}, 96^{\circ} 31^{\prime} 33.0^{\prime \prime} \mathrm{W}$ \\
\hline Zipolite, Oaxaca & $15^{\circ} 39^{\prime} 37.0^{\prime \prime} \mathrm{N}, 96^{\circ} 30^{\prime} 38.8^{\prime \prime} \mathrm{W}$ \\
\hline Puerto Chiapas, Chiapas & $14^{\circ} 42^{\prime} 11.4^{\prime \prime} \mathrm{N}, 92^{\circ} 24^{\prime} 36.8^{\prime \prime} \mathrm{W}$ \\
\hline
\end{tabular}

\footnotetext{
$\mathrm{LCP}=$ Luis Fernando Carrera Parra

MLY $=$ Monserrat López-Yllescas

$\mathrm{NHH}=$ Nadia Valeria Herrera Herrera

PHM = Paulina Hernández-Moreno

RBZ = José Rolando Bastida-Zavala

RGF $=$ Rebeca Granja-Fernández

RRB = Raúl Ramírez-Barragán

$\mathrm{RXP}=$ Rodrigo Xavier-Pacheco

SGG = Sergio Guendulain-García

SGM = María del Socorro García-Madrigal

$\mathrm{SS}=$ Saúl Serrano

SSV $=$ Sergio I. Salazar-Vallejo

TVG $=$ Tulio F. Villalobos-Guerrero

VAR = Víctor Alvarado-Ruiz
} 


\title{
Results
}

\author{
Phylum Sipuncula Sedgwick, 1898 \\ Family Sipunculidae Rafinesque, 1814 \\ Genus Sipunculus Linnaeus, 1766 \\ Subgenus Sipunculus (Sipunculus) Linnaeus, 1766
}

Sipunculus (Sipunculus) cf. polymyotus Fisher, 1947

Figs 1-2

\section{Type locality of nominal species}

Key West, Florida (Fisher 1947: 354-358, pl. 10, fig. 24).

\section{Material examined}

MEXICO • 1; Oaxaca, Puerto Ángel, Boquilla Beach; 15²0'58" N, 96²7'54" W; 21 Mar. 2016; FRE leg.; depth 5 m, in sand; UMAR-SIPU 106.

\section{Description}

Trunk $80 \mathrm{~mm}$ in length (Fig. 1A). Introvert $10 \%$ of total length; with triangular papillae and associated microbivalves (Fig. 1B-D). Transparent and iridescent body. Tentacular membrane with two large ventral lobes and two smaller dorsal lobes with margin greatly subdivided (Fig. 1E). Longitudinal and circular musculature in bands, with 49 longitudinal muscle bands (LMBs). Gut with post-esophageal loop. Two pairs of retractor muscles, each ventral retractor muscle attached to six LMBs starting from second band after ventral nerve cord; each dorsal retractor muscle attached to five LMBs starting from $15^{\text {th }}$ band after ventral nerve cord (Fig. 2A). Most LMBs split and double in posterior end. Brain with approximately ten digitate processes, large, conspicuous, leaf-like flaps and long strings (Fig. 2B). A pair of brownish nephridia with irregular knobby surfaces, about $10 \%$ of trunk length (Fig. 2C). Anus with small prominences surrounding its boundary (Fig. 2D). Nephridiopore anterior to anus. Spindle muscle not attached to body wall posteriorly.

\section{Morphological remarks}

The prominences of the anus are conspicuous. This morphological feature was not described by Cutler (1994), or even by Fisher (1947). The prominences are not related with the elevation of the anus or the fixation process.

\section{Taxonomic remarks}

Fisher (1947) described Sipunculus polymyotus from Key West, Florida and later S. natans Fisher, 1954 from Santa Inés Bay, on Gulf coast of Baja California, Mexico. Cutler (1994) synonymized S. natans with $S$. polymyotus. The principal morphological difference between the two species is the number of longitudinal muscle bands. Sipunculus polymyotus has 53-55 while $S$. natans has 49-52. The single specimen of $S$. cf. polymyotus from the Southern Mexican Pacific revised in this study has 49 LMB, i.e., more similar to conditions described for $S$. natans (Table 2).

Once more specimens of Sipunculus (S.) cf. polymyotus become available, the name $S$. natans could be revalidated. This hypothesis is based on some recent papers where the use of molecular data has rejected the supposed wide distribution of some species (Staton \& Rice 1999; Kawauchi \& Giribet 2010, 2014; Schulze et al. 2012; Johnson et al. 2016; Silva-Morales et al. 2019). 


\section{Habitat}

Subtidal (5 m); in sand.

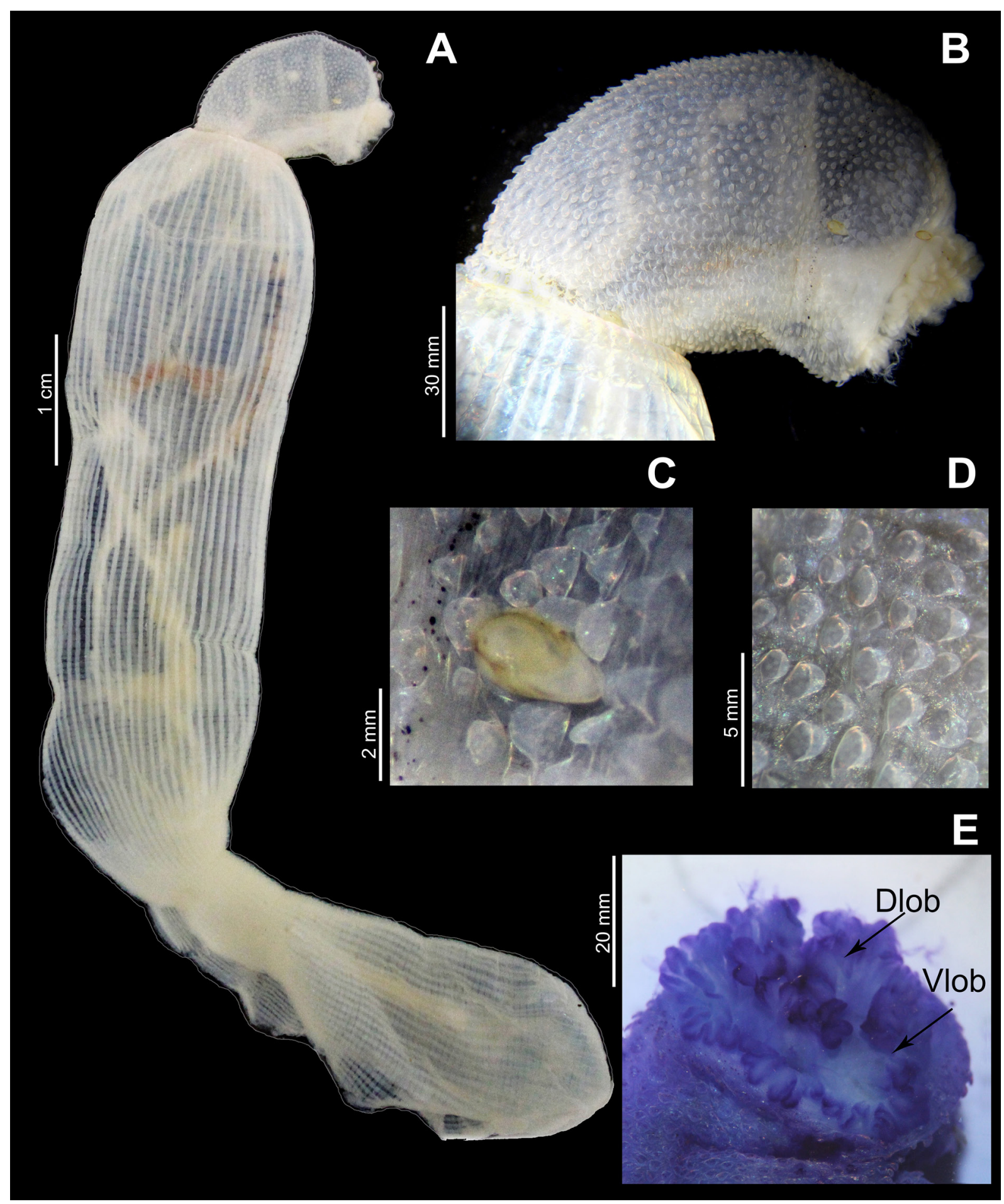

Fig. 1. Sipunculus cf. polymyotus Fisher, 1947 from Oaxaca, Mexico lateral view. A. External morphology. B. Introvert. C. Microbivalve associated with introvert papillae. D. Triangular introvert papillae. E. Peripheral tentacles stained in methyl blue. Abbreviations: Dlob = dorsal lobe; Vlob $=$ ventral lobe. 


\section{Distribution}

Boquilla Beach, Oaxaca, Mexico.

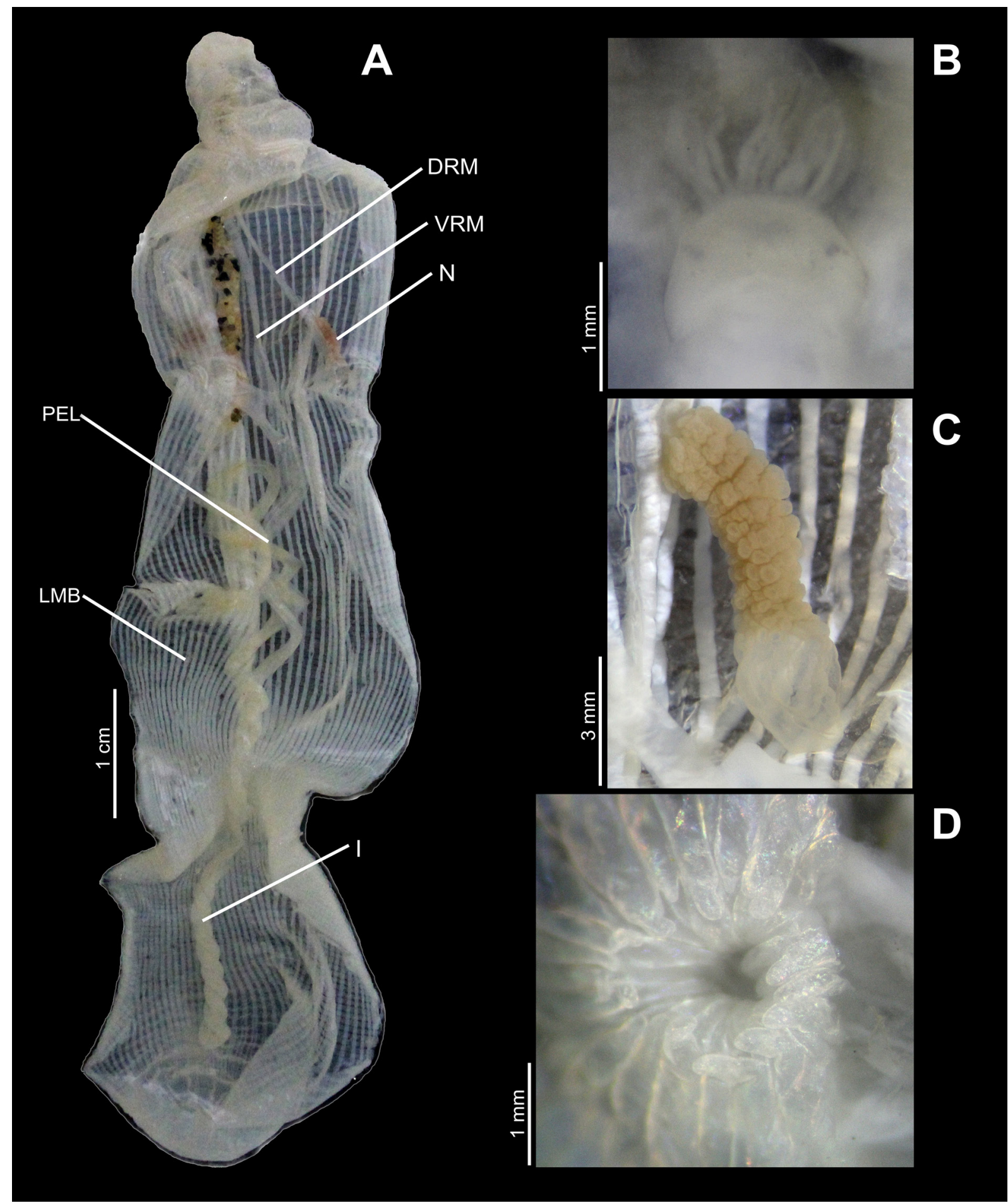

Fig. 2. Sipunculus cf. polymyotus Fisher, 1947 from Oaxaca, Mexico. A. Internal morphology. B. Digitate processes of brain. C. Nephridium. D. Anus (black row indicates the prominences of the anus). Abbreviations: $\mathrm{DRM}=$ dorsal retractor muscles; $\mathrm{I}=$ intestine; $\mathrm{LMB}=$ longitudinal muscle bands; $\mathrm{N}=$ nephridium; $\mathrm{PEL}=$ post esophageal loop; $\mathrm{VRM}=$ ventral retractor muscles. 
SILVA-MORALES I. \& GÓMEZ-VÁSQUEZ J.D., Sipunculans from the Southern Mexican Pacific

Table 2. Comparison between some species of Sipunculus Linnaeus, 1766 from tropical America.

\begin{tabular}{cccc}
\hline & S. polymyotus & S. natans & S. cf. polymyotus \\
\hline Reference & Fisher (1947) & Fisher (1954) & this paper \\
Locality & Key West, Florida, & Santa Inez Bay, on Gulf coast & Boquilla Beach, \\
Depth & USA & of Baja California, Mexico & Oaxaca, Mexico \\
Number of LMB & $?$ & $?$ & $5 \mathrm{~m}$ \\
Trunk length & $53-55$ & $49-52$ & 49 \\
Prominences of the anus & $28 \mathrm{~cm}$ & $15 \mathrm{~cm}$ & $8 \mathrm{~cm}$ \\
\hline
\end{tabular}

Family Siphonosomatidae Kawauchi, Sharma \& Giribet, 2012

Genus Siphonosoma Spengel, 1912

Siphonosoma cf. cumanense (Keferstein, 1867)

Fig. 3

\section{Type locality of nominal species}

Cumana, Venezuela (Keferstein 1867: 53-55, pl. 6, figs 19-21).

\section{Material examined}

MEXICO • 1; Oaxaca, Huatulco, Santa Cruz Beach; 1545'10" N, 9607'49" W; 1 Dec. 2016; JGV leg.; depth $3 \mathrm{~m}$, in sand; UMAR-SIPU 104.

\section{Description}

Pinkish and damaged trunk (Fig. 3A). Introvert and trunk with rectangular papillae (Fig. 3D). Approximately 80 peripheral tentacles of equal length (Fig. 3C). Without hooks. Musculature divided in 20 anastomosing longitudinal muscle bands (Fig. 3B). Two pairs of retractor muscles originating at same level along anterior-posterior axis. Dark brown nephridia occupying less than $10 \%$ of trunk. Villi present in contractile vessel. Spindle muscle attached to body wall posteriorly.

\section{Remarks}

This species is similar to Siphonosoma cumanense (Keferstein, 1867), but the widespread distribution is unlikely.

\section{Habitat}

Subtidal (3 m); in sand.

\section{Distribution}

Santa Cruz Beach, Oaxaca, Mexico.

Siphonosoma cf. vastum (Selenka \& Bülow in Selenka, 1883)

Fig. 4

\section{Type locality of nominal species}

Jaluit, Marshall Islands (Selenka 1883: 103-104, pl. 12, fig. 171, pl. 13, fig. 179). 


\section{Material examined}

MEXICO • 1; Oaxaca, San Agustín Bay; 15²1'21" N, 96²14'11" W; 24 Oct. 2004; SCJ leg.; depth 3 m, under rock in sand; UMAR-SIPU 105.



Fig. 3. Siphonosoma cf. cumanense (Keferstein, 1867) from Oaxaca, Mexico. A. External morphology. B. Internal morphology. C. Peripheral tentacles. D. Folds of the body wall. Abbreviations: DRM = dorsal retractor muscles; I = intestine; $\mathrm{LMB}=$ longitudinal muscle bands; $\mathrm{M}=$ membrane of musculature; $\mathrm{N}=$ nephridium; $\mathrm{T}=$ tentacles; $\mathrm{VRM}=$ ventral retractor muscles. 


\section{Description}

Trunk $150 \mathrm{~mm}$ in length in preserved specimens (Fig. 4A), $300 \mathrm{~mm}$ in living specimens. More than 60 filiform tentacles. Introvert with dispersed orange papillae (Fig. 4C) and reddish region with rectangular

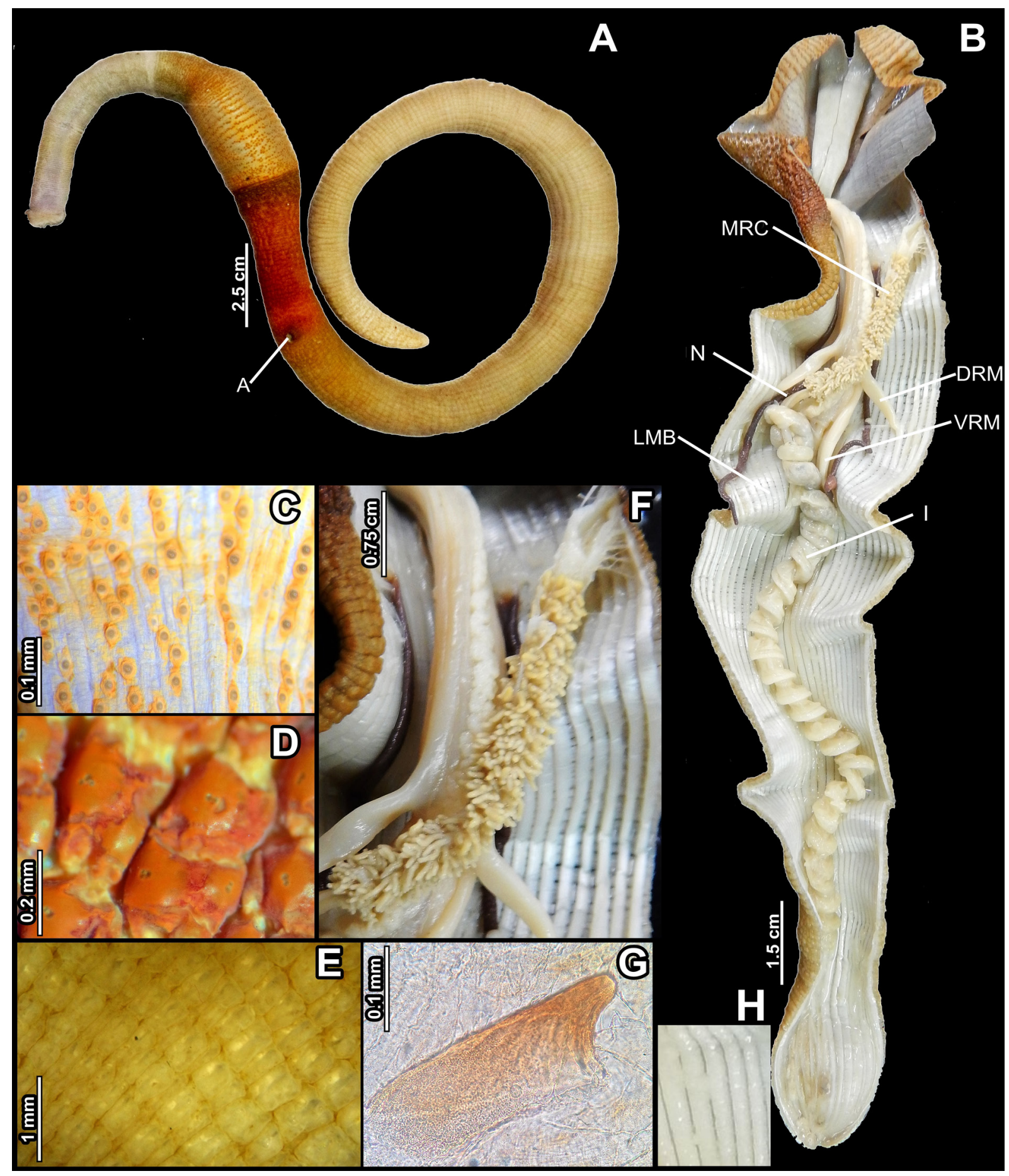

Fig. 4. Siphonosoma cf. vastum (Selenka \& Bülow in Selenka, 1883) from Oaxaca, Mexico. A. External morphology. B. Internal morphology. C. Introvert papillae. D. Posterior introvert papillae. E. Trunk wall from the median region of the trunk. F. Multiple rectal caeca. G. Hook. H. Longitudinal muscle bands. Abbreviations: $\mathrm{A}=$ anus; $\mathrm{DRM}=$ dorsal retractor muscles; $\mathrm{I}=$ intestine; $\mathrm{LMB}=$ longitudinal muscle bands; $\mathrm{MRC}=$ multiple rectal caeca; $\mathrm{N}=$ nephridium; $\mathrm{VRM}=$ ventral retractor muscles. 
Table 3. Comparison between the species of Siphonosoma Spengel, 1912 from the Pacific Ocean.

\begin{tabular}{|c|c|c|c|}
\hline & S. australe & S. vastum & S. cf. vastum \\
\hline Reference & Keferstein (1865) & Selenka et al. (1883) & this paper \\
\hline Type locality & Sydney, Australia & Jaluit, Marshall Islands & Oaxaca, Mexico \\
\hline Depth & $?$ & $?$ & $3 \mathrm{~m}$ \\
\hline Multiple rectal caeca & absent & present in $60 \%$ of rectum & present in $90 \%$ of rectum \\
\hline $\begin{array}{c}\text { Number of } \\
\text { longitudinal muscle bands }\end{array}$ & $15-20$ & 27 & 26 \\
\hline Trunk length & $200 \mathrm{~mm}$ & $95 \mathrm{~mm}$ & $200 \mathrm{~mm}$ \\
\hline Live coloration of body & transparent & gray to yellow & light brown to red \\
\hline Attachment of ventral muscles & $?$ & $\begin{array}{l}\text { left } 2-5 \\
\text { left } 2-6\end{array}$ & $\begin{array}{l}\text { right } 2-6 \\
\text { right } 2-5,6\end{array}$ \\
\hline Attachment of dorsal muscles & $?$ & $\begin{array}{c}\text { left } 9 \\
\text { left 9-10 }\end{array}$ & $\begin{array}{c}\text { right } 8-9 \\
\text { right } 10\end{array}$ \\
\hline
\end{tabular}

papillae (Fig. 4D). Trunk with light brown body wall (Fig. 4E). More than 100 rings of claw-shaped hooks (Fig. 4G). Twenty-six anastomosing longitudinal muscle bands (Fig. 4H). Two long, tiny and dark brown free nephridia occupying $40 \%$ of trunk, about $35 \%$ attached to body wall. Two pairs of retractor muscles; dorsal pair attached to five bands starting from second band after ventral nerve cord, ventral pair attached to nine bands (Fig. 4B). Multiple rectal caeca covering 90\% of rectum (Fig. 4F). Spindle muscle attached posteriorly. Nephridiopore almost at same level of anus.

\section{Remarks}

The species is similar to Siphonosoma australe australe (Keferstein, 1865), described from Sydney, Australia, and to S. vastum (Selenka \& Bülow in Selenka, 1883), described from Jaluit, Marshall Islands (Table 3). Siphonosoma cf. vastum differs from $S$. australe australe in that the former species has multiple rectal caeca in $90 \%$ of the rectum, which are absent in the latter. According to Cutler et al. (1992), S. vastum is able to disperse across the entire Tropical Pacific Ocean. However, the nominal species is different from $S$. cf. vastum from Mexico in many diagnostic characters, mainly the coverage of the multiple rectal caeca in the rectum and the attachment of the muscles in the body wall (Table 2). This species is a possibly a new species; however, more specimens are needed to describe it.

\section{Habitat}

Subtidal (3 m); in sand.

\section{Distribution}

San Agustín Bay, Oaxaca, Mexico.

Family Golfingiidae Stephen \& Edmonds, 1972

Genus Themiste Gray, 1828

Subgenus Themiste (Themiste) Gray, 1828

Themiste (Themiste) hennahi Gray, 1828

Fig. 5

Themiste hennahi Gray, 1828: 8, pl. 6, fig. 4-4a (type locality: Peru). 
Dendrostoma zostericola Chamberlin, 1920: 30 (type locality: Laguna Beach, California).

Dendrostomum schmitti Fisher, 1952: 422, fig. 87f (type locality: Independencia Bay, Peru).

Dendrostoma zostericola - Fisher 1952: 411-415, fig. 87a, pl. 30, fig. 1, pls 31-32 (Ensenada, Baja California, Mexico).
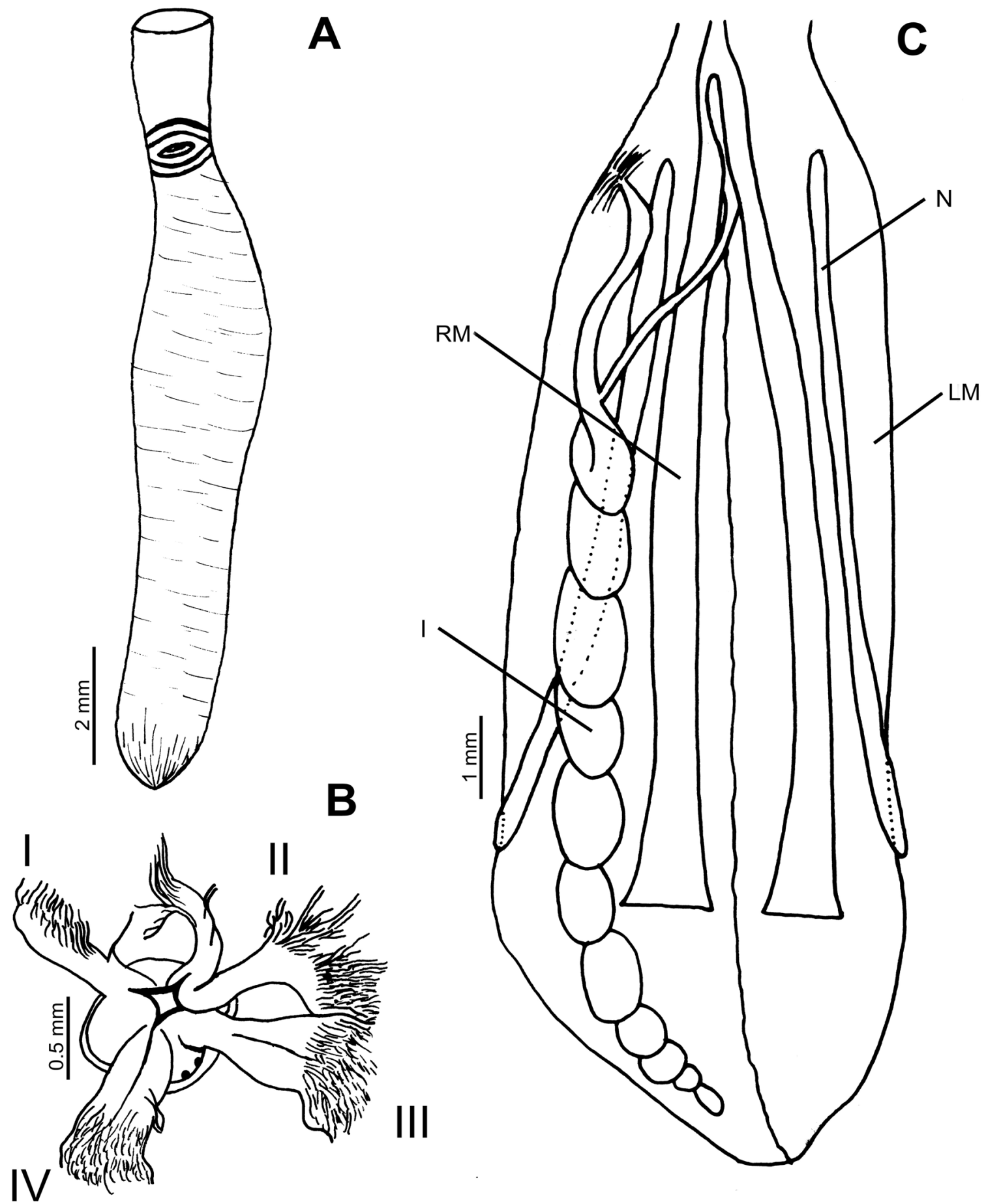

Fig. 5. Themiste (Themiste) hennahi Gray, 1828 from Oaxaca, Mexico. A. External morphology. B. Tentacular crown. C. Internal morphology. Abbreviations: I = intestine; LM = longitudinal muscle; $\mathrm{N}=$ nephridium; $\mathrm{RM}=$ retractor muscles. 


\title{
Material examined
}

MEXICO • 1; Oaxaca, San Agustín Bay; 1541'21" N, 96 ${ }^{\circ} 14^{\prime} 11^{\prime \prime}$ W; 10 Feb. 2007; depth 2 m, in Porites; UMAR-SIPU 103.

\section{Description}

Specimen damaged. Trunk white in color, $15 \mathrm{~mm}$ in length (Fig. 5A). Introvert $5 \mathrm{~mm}$ in length, without hooks or pigmented collar. Tentacular crown with four asymmetrical stems, giving appearance of six primary stems (Fig. 5B). Peripheral tentacles with pigment spots. Longitudinal muscle of body wall gathered in uniform continuous layer. Nephridiopores opening at level of anus. A pair of retractor muscles attached to body wall at $75 \%$ of trunk length (Fig. 5C). Five tubular extensions, very fragile (not illustrated but observed).

\section{Remarks}

The type locality from Themiste hennahi is Peru. Unfortunately, Gray (1828) did not specify the locality. The species has also been recorded from Laguna Beach, Southern California, and Ensenada, Baja California (Fisher 1952), under different names (Cutler 1994). We advise the revision of the specimens from the Subtropical Eastern Pacific to confirm the widespread distribution of T. hennahi.

\section{Habitat}

Subtidal (2 m); in dead coral (Porites).

\section{Distribution}

Southern California, Baja California and Tropical Eastern Pacific (Oaxaca and Peru).

\author{
Family Phascolosomatidae Stephen \& Edmonds, 1972 \\ Genus Phascolosoma Leuckart, 1828 \\ Subgenus Phascolosoma (Phascolosoma) Leuckart, 1828
}

Phascolosoma (Phascolosoma) cf. perlucens Baird, 1868

Fig. 6

\section{Type locality of nominal species}

Jamaica (Baird 1868: 90-91, pl. 10, fig. 2-2a).

\section{Material examined}

MEXICO - Guerrero • 2; La Quebrada; 16 $50^{\prime} 44^{\prime \prime}$ N, 99 54'54" W; 21 Sep. 2001; depth 15-20 m, in

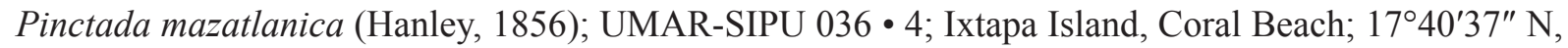
$101^{\circ} 39^{\prime} 20^{\prime \prime} \mathrm{W}$; 19 Sep. 2007; in dead coral with algae; UMAR-SIPU $037 \bullet 52$; Ixtapa Island; $17^{\circ} 40^{\prime} 37^{\prime \prime} \mathrm{N}$, 101 ${ }^{\circ} 39^{\prime} 20^{\prime \prime}$ W; 24 Sep. 2007; SGM leg.; in pier piles; UMAR-SIPU 038 • 8; Punta Maldonado Beach; $16^{\circ} 19^{\prime} 39^{\prime \prime}$ N, 98 34'15" W; 23 Sep. 2007; SGM leg.; in algae; UMAR-SIPU 039 • 8; Marquelia, Las Peñitas Beach; 16³3'16" N, 9846'21" W; 22 Sep. 2007; SGM leg.; UMAR-SIPU 040 • 8; Manzanillo Beach; $16^{\circ} 50^{\prime} 31^{\prime \prime}$ N, 99 $9^{\circ} 4^{\prime} 38^{\prime \prime} \mathrm{W}$; 22 Sep. 2007; in pier piles with sponge; SGM leg.; UMAR-041 • 3;

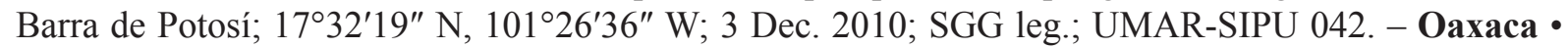

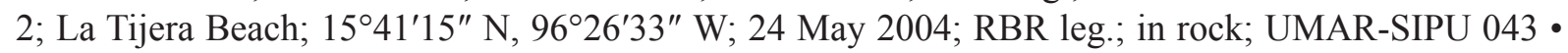
18; Estacahuite Beach; $15^{\circ} 40^{\prime} 05^{\prime \prime} \mathrm{N}, 9^{\circ} 28^{\prime} 53^{\prime \prime} \mathrm{W}$; 18 Apr. 2005; SGM leg.; in rocks with carbonate;

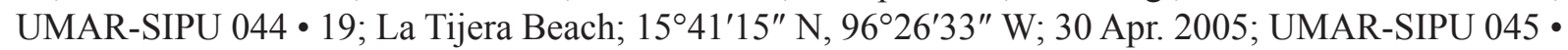
12; Estacahuite Beach; $15^{\circ} 40^{\prime} 05^{\prime \prime} \mathrm{N}, 9^{\circ} 28^{\prime} 53^{\prime \prime} \mathrm{W}$; 10 Sep. 2005; in dead coral; UMAR-SIPU 046 • 


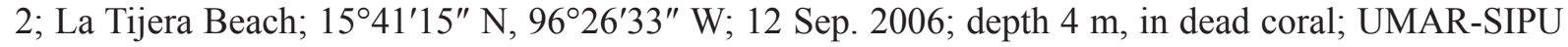
048 • 3; Chachacual Bay, Jicaral Beach; 1542'39" N, 96²'11" W; 10 Feb. 2007; depth 5.6 m, in Porites sp.; UMAR-SIPU 049 • 2; San Agustín Bay; 1541'21" N, 96²14'11" W; 24 Feb. 2007; UMARSIPU 050 • 2; Chacahua; 15 58'07" N, 97³2'09" W; 13 Apr. 2007; in rocks; UMAR-SIPU 052 • 45;

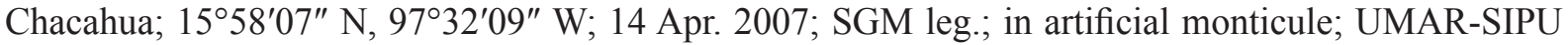


1; Zipolite, Playa del Amor; 15³9'37" N, 96³0'38" W; 13 Apr. 2007; UMAR-SIPU 055 • 1; Chacahua;

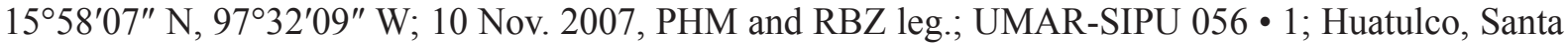
Cruz Beach; $15^{\circ} 45^{\prime} 10^{\prime \prime} \mathrm{N}, 96^{\circ} 07^{\prime} 49^{\prime \prime} \mathrm{W}$; 14 Dec. 2007; BMD and PHM leg.; depth $0.5 \mathrm{~m}$, in pier piles; UMAR-SIPU 057 • 4; Panteón Beach; 15³9'50" N, 96²9'42" W; 16 Apr. 2008; JDG and GGG leg.;

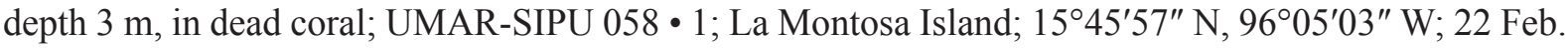
2010; RGF and SGG leg.; depth 3.6 m, in Pocillopora damicornis (Linnaeus, 1758); UMAR-SIPU 059 •

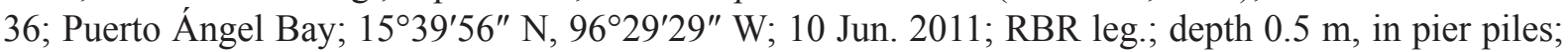
UMAR-SIPU 060 • 4; Agua Blanca Beach; 1543'58" N, 96²4'38" W; 27 Apr. 2012; KLT leg.; UMARSIPU 061 • 9; Puerto Ángel Bay; 15³9'56" N, 96²9'29" W; 28 May 2014; ISM and JGV leg.; in pier

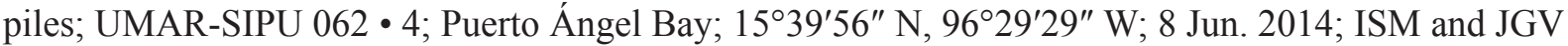
leg.; in pier piles; UMAR-SIPU 063 • 3; Chacahua, Cerro Hermoso Beach; 15 $5^{\circ} 58^{\prime} 08^{\prime \prime}$ N, 97 $32^{\prime} 06^{\prime \prime} \mathrm{W}$;

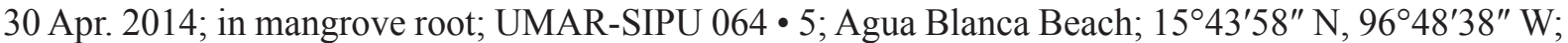
30 Apr. 2014; UMAR-SIPU 065 • 8; Boquilla Beach; 1540'58" N, 96²7'54" W; 22 May 2014; UMAR-

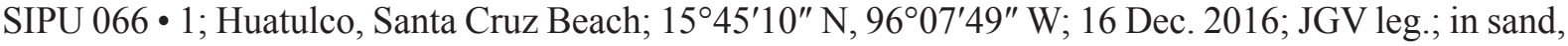
UMAR-SIPU 067 • 3; Violín Beach; 1544'24" N, 9607'38" W; 1 Dec. 2016; JGV leg.; UMAR-SIPU

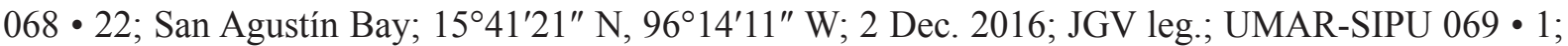

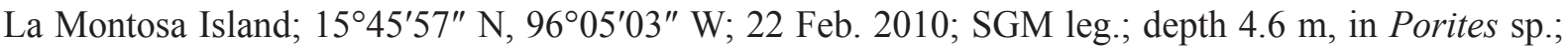
UMAR-SIPU 070. - Chiapas • 19; Puerto Chiapas; 14²4'11" N, 92²4'36" W; 20 Sep. 2011; RBZ leg.; in pier piles, in rock with oyster; UMAR-SIPU 051.

\section{Description}

Trunk 3-18 mm in length. Introvert as long as trunk (Fig. 6A), with patches of dark brown pigment in dorsal part. Reddish conical papillae on dorsal base of introvert, posterior to anus (Fig. 6E-F). Introvert bears 15 rings of hooks (Fig. 6D). Hooks with secondary tooth and basal triangle (Fig. 6C). Fourteen digitiform tentacles encircling nuchal organ (Fig. 6D). Longitudinal muscles of body wall combined into bands. Four retractor muscles. Two brown nephridia occupy $30 \%$ of trunk (Fig. 6B). Spindle muscle attached posteriorly.

\section{Remarks}

Although there are no morphological characters to support that the populations of Phascolosoma perlucens from the Caribbean and the Eastern Pacific are different species, the molecular data provides strong evidence of a differentiation between both populations (Kawauchi \& Giribet 2010); therefore, we propose to consider this species as being near to the nominal species. It is possible that the specimens recorded here and other records from the Tropical Eastern Pacific (Fisher 1952; Dean 2001; Dean et al. 2010) are a new species.

\section{Habitat}

Intertidal and subtidal $(20 \mathrm{~m})$; as epibionts of Pinctada mazatlantica, in dead coral, between the fouling of pier piles, in macroalgae, in a sabellariid reef, in mangrove roots and in sand.

\section{Distribution}

Southern Mexican Pacific, from Ixtapa, Guerrero to Puerto Chiapas. 


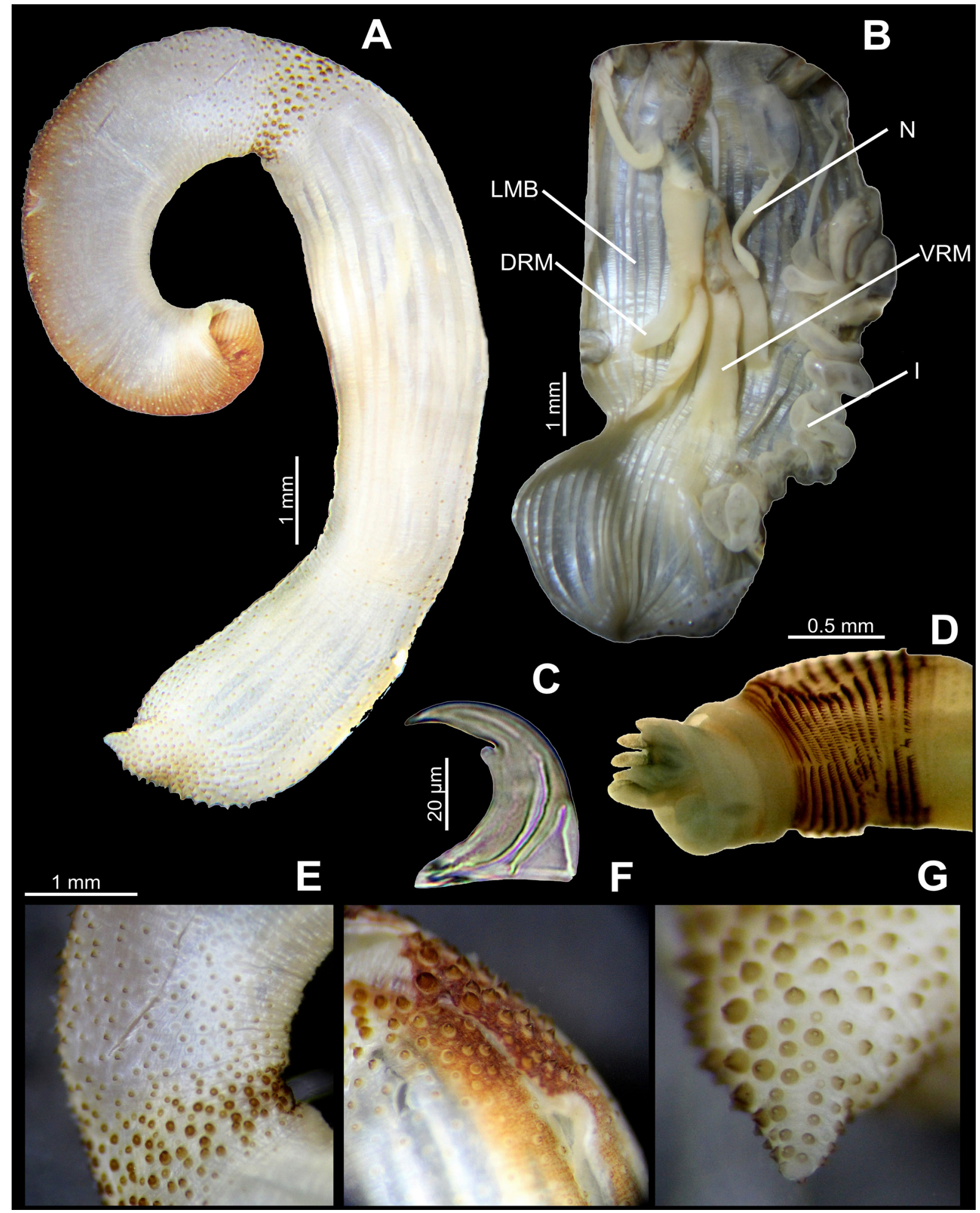

Fig. 6. Phascolosoma cf. perlucens Baird, 1868 from the Southern Mexican Pacific. A. External morphology. B. Internal morphology. C. Hook. D. Tentacles and rings of hooks. E. Preanal papillae, lateral view. F. Preanal papillae, dorsal view. G. Caudal papillae. Abbreviations: DRM = dorsal retractor muscles; I = intestine; LMB = longitudinal muscle bands; $\mathrm{N}=$ nephridium; VRM = ventral retractor muscles. 
SILVA-MORALES I. \& GÓMEZ-VÁSQUEZ J.D., Sipunculans from the Southern Mexican Pacific

Phascolosoma (Phascolosoma) puntarenae (Grube \& Örsted in Grube, 1858), reinstatement Fig. 7

Phascolosoma puntarenae Grube \& Örsted in Grube, 1858: 13 (type locality: Puntarenas, Costa Rica).

Phascolosoma puntarenae - Fisher 1952: 430-432, pl. 36, figs 1-2, pl. 37, figs 1-3, pl. 39, fig. 3 (from Gulf of California to Panama, in rocks).

Phascolosoma puntarena - Brusca 1980: 127 (Gulf of California, in rocks).

Phascolosoma nigrescens (non Keferstein, 1865) - Cutler et al. 1992: 154-156 (Costa Rica, in tidal pools and under rocks). - Dean 2001: 63 (Pacific of Costa Rica). - Dean et al. 2010: 63 (Cocos Island, Costa Rica, in calcareous rock, 0-15 m).

\section{Material examined}

MEXICO - Guerrero • 1; Roqueta Island; 16 $49^{\prime} 19^{\prime \prime}$ N, 99 54'17" W; 21 Sep. 2006; in sabellariid tubes; UMAR-SIPU 021 • 1; La Quebrada; 16 $50^{\prime} 44^{\prime \prime}$ N, 99 $54^{\prime} 54^{\prime \prime}$ W; 26 Sep. 2007; depth 15 m, in

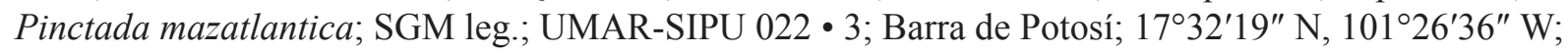
3 Dec. 2010; SGG leg.; UMAR-SIPU 023. - Oaxaca • 1; Puerto Escondido; $15^{\circ} 51^{\prime} 34^{\prime \prime}$ N, $97^{\circ} 03^{\prime} 50^{\prime \prime}$ W; 4 Jul. 2004; SS leg.; UMAR-SIPU 0242 • Estacahuite Beach; $15^{\circ} 40^{\prime} 05^{\prime \prime} \mathrm{N}, 9^{\circ} 28^{\prime} 53^{\prime \prime} \mathrm{W}$; 10 Sep. 2005;

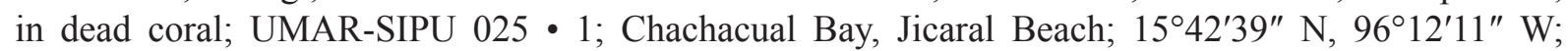
14 Dec. 2006; TRC leg.; depth $1 \mathrm{~m}$, in dead coral; UMAR-SIPU 026 • 1; San Agustín Bay; 1541'21" N, 96 $14^{\prime} 11^{\prime \prime} \mathrm{W} ; 10$ Feb. 2007; depth $15.3 \mathrm{~m}$, in Porites; UMAR-SIPU 027• 3; Puerto Ángel Bay; $15^{\circ} 39^{\prime} 56^{\prime \prime}$ N, 96²9'29" W; 28 Apr. 2008; TFG leg.; in dead coral; UMAR-SIPU 028 • 1; Panteón Beach; 15³9'50" N, 96²9'42" W; 27 May 2008; MLY leg.; depth 3 m; UMAR-SIPU 030 • 1; La Montosa

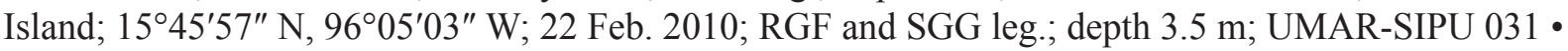
3; Camarón Beach; 15³9'45" N, 96³1'33" W; 6 Apr. 2013; in dead coral; UMAR-SIPU 032 • 3; Cerro

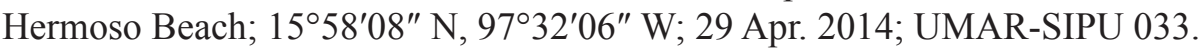

\section{Description}

Trunk $10 \mathrm{~mm}$ in length (Fig. 7A). Light brown trunk with uniform dome-shaped papillae, some with black pigment randomly distributed (Fig. 7D-E). Introvert with bands of dark pigmentation and more than 100 complete and incomplete rings of hooks. Hooks with clear streak expanded near midpoint of vertical and middle of horizontal portions (Fig. 7F-G). Secondary tooth almost indistinct, protuberance of streak short. Fourteen tentacles encircling nuchal organ (Fig. 7C). Longitudinal muscles of body wall gathered into anastomosing bands. Four retractor muscles. Nephridia about $40 \%$ of trunk length, open at same level as anus (Fig. 7B). Spindle muscle attached posteriorly.

\section{Remarks}

Cutler \& Cutler (1990) considered Phascolosoma (P.) puntarenae from Puntarenas, Costa Rica, as a synonym of $P$. $(P$.) nigrescens from Fiji. Nevertheless, we found a difference between the hooks of the type material of $P$. nigrescens illustrated by Selenka (1883) and those in the illustrations of Fisher (1952) of P. puntarenae from Baja California, Costa Rica and Panama. The hooks of $P$. nigrescens have a conspicuous secondary tooth and the protuberance of the streak is a sharp point, whereas the hooks of $P$. puntarenae do not have a well-developed secondary tooth and the protuberance of the streak is a flattened point (Fig. 8F-G).

\section{Habitat}

Intertidal to subtidal $(15 \mathrm{~m})$; in sabellariid tubes, as epibionts of Pinctada mazatlanica, in dead coral and in Porites.

\section{Distribution}

From the Gulf of California to Panama. 




Fig. 7. Phascolosoma (Phascolosoma) puntarenae Grube \& Örsted in Grube, 1858 from the Southern Mexican Pacific. A. External morphology. B. Internal morphology. C. Nuchal tentacles. D. Trunk papillae, macroscopic view. E. Trunk papillae, microscopic view. F. Hook of proximal rings. G. Hook of distal rings. Abbreviations: $\mathrm{DRM}=$ dorsal retractor muscles; $\mathrm{I}=$ intestine; $\mathrm{LMB}=$ longitudinal muscle bands; $\mathrm{N}=$ nephridium; VRM = ventral retractor muscles. 
Genus Apionsoma Sluiter, 1902

Subgenus Apionsoma (Apionsoma) Sluiter, 1902

Apionsoma (Apionsoma) hespera (Chamberlin, 1920) comb. nov., reinstatement

Figs $8 \mathrm{~A}-\mathrm{C}, 9$

Phascolosoma hespera Chamberlin, 1920: 31 (type locality: Balboa, Newport Bay, Orange County, California).

Golfingia hespera - Fisher 1952: 393-395, pl. 24, figs 1-5 (San Lucas Cove, southern Santa Rosalía, Gulf of California, commensals in Cerianthus Delle Chiaje, 1841 tubes; Balboa, Newport Bay, Orange County, California).

Golfingia (Mitosiphon) hespera - Amor 1975: 115-116, pl. 2, figs a-d (Ancón, Peru in Phragmatopoma Mörch, 1863 and Perumytilus Olsson, 1961, in rocks).

\section{Material examined}

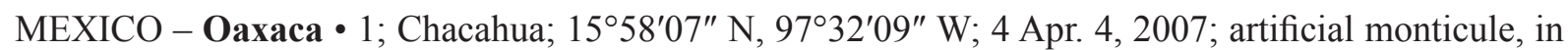
rocks; UMAR-SIPU 101 • 3; Panteón Beach; 15³9'50" N, 96²9'42" W; 24 Apr. 2012; NVHH leg.; UMAR-SIPU 102.

\section{Description}

Trunk $8 \mathrm{~mm}$ in length, spindle-shaped (Fig. 9A). Introvert seven times trunk length. Posterior end of trunk with numerous distinctive papillae (Fig. 9C-D). More than 40 rings of hooks, with 7-8 basal spinelets. Spinelets longer than principal tooth (Fig. 9E). Body wall with continuous muscle layers. Four retractor muscles equidistant from ventral nerve cord near middle of trunk. Nephridia bilobed, with
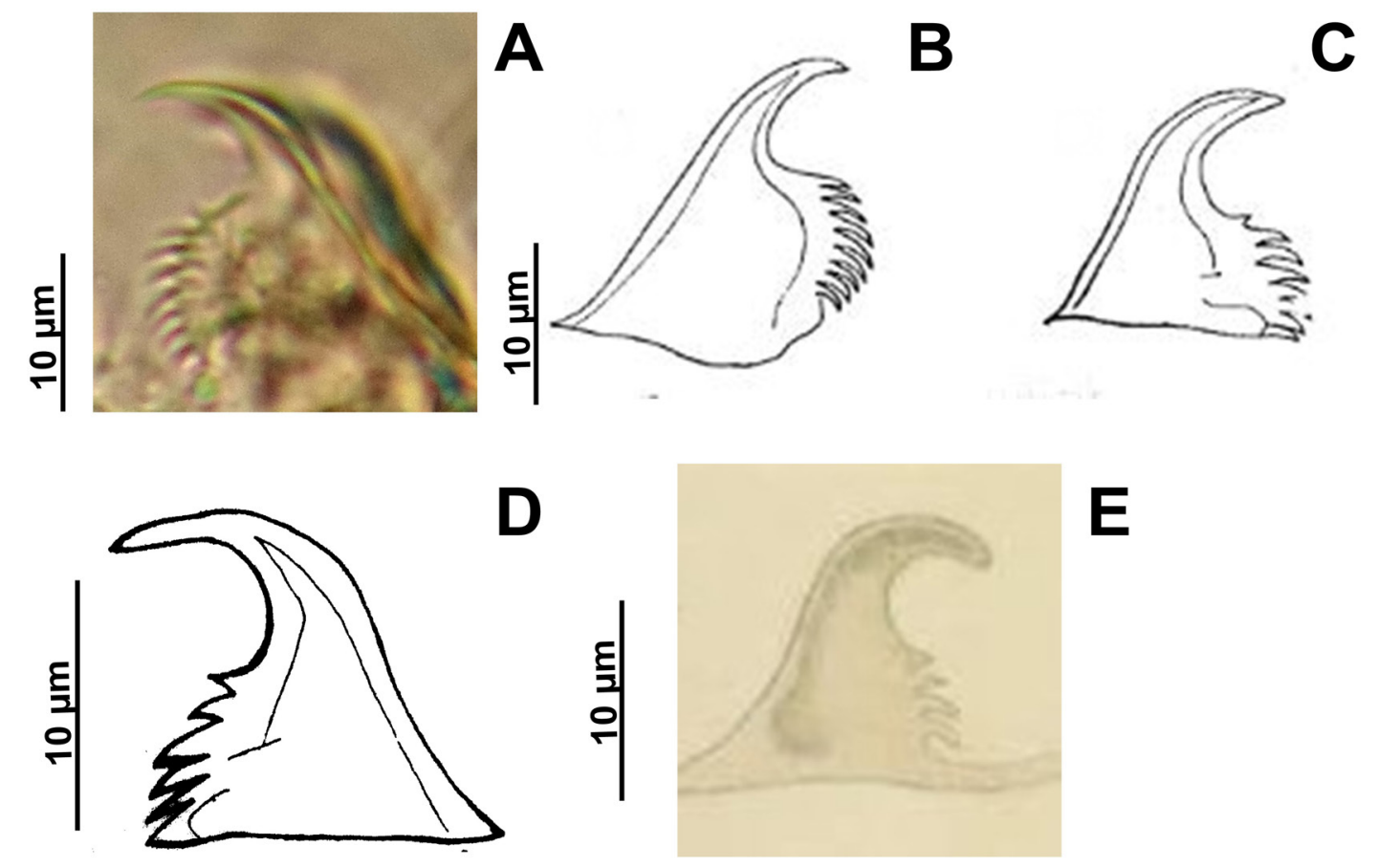

Fig. 8. - A-C. Hooks of Apionsoma (Apionsoma) hespera (Chamberlin, 1920) comb. nov. A. From Oaxaca, Mexico. B-C. From Peru. - D-E. Hooks of Apionsoma misakianum (Ikeda, 1904). D. From Misaki, Japan. E. From Japan. B-C: from Amor (1975); D: from Ikeda (1904); E: from Cutler et al. (1984). 
unequal lobules occupying almost $90 \%$ of trunk length (Fig. 9B). Spindle muscle attached to body wall posteriorly.

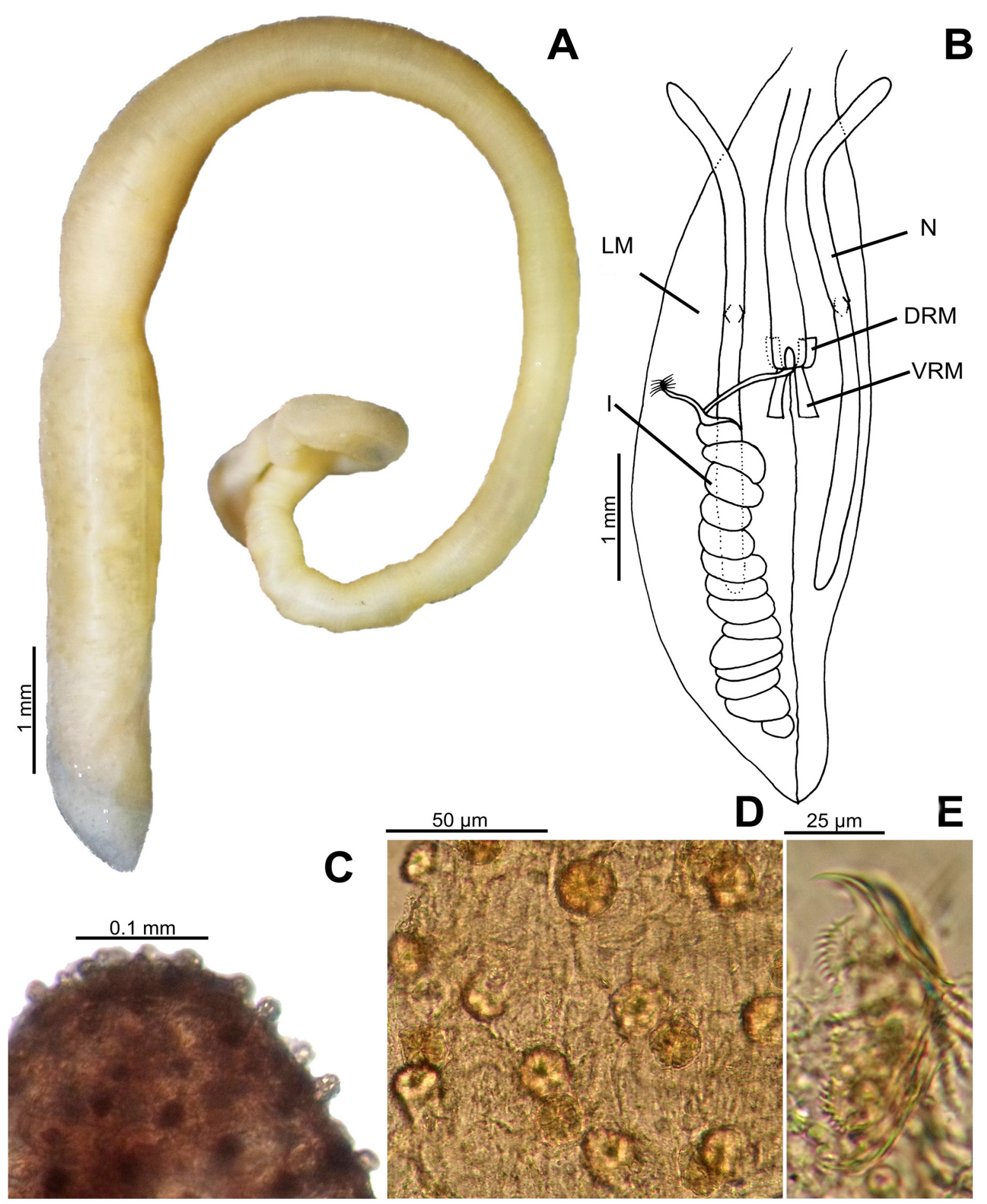

Fig. 9. Apionsoma (Apionsoma) hespera (Chamberlin, 1920) comb. nov. from the Southern Mexican Pacific. A. External morphology. B. Internal morphology. C. Caudal papillae. D. Caudal papillae, amplified view. E. Hooks. Abbreviations: DRM = dorsal retractor muscles; $\mathrm{I}=$ intestine; $\mathrm{LM}=$ longitudinal muscle; $\mathrm{N}=$ nephridium; $\mathrm{VRM}=$ ventral retractor muscles. 
SILVA-MORALES I. \& GÓMEZ-VÁSQUEZ J.D., Sipunculans from the Southern Mexican Pacific

Table 4. Comparison between the species of Apionsoma Sluiter, 1902.

\begin{tabular}{cccc}
\hline & Phascolosoma hespera & $\begin{array}{c}\text { Apionsoma (A.) } \\
\text { misakianum }\end{array}$ & $\begin{array}{c}\text { Apionsoma (A.) hespera } \\
\text { comb. nov. }\end{array}$ \\
\hline Reference & $\begin{array}{c}\text { Chamberlin (1920) } \\
\text { Laguna Beach, } \\
\text { California, USA }\end{array}$ & $\begin{array}{c}\text { Ikeda (1904) } \\
\text { Misaki, Japan }\end{array}$ & $\begin{array}{c}\text { this paper } \\
\text { Panteón Beach, } \\
\text { Oaxaca, Mexico }\end{array}$ \\
$\begin{array}{c}\text { Number of rings of hooks } \\
\text { Basal spinelets }\end{array}$ & $30-50$ & 60 & 40 \\
$\begin{array}{c}\text { Proportion between distance } \\
\text { of dorsal to ventral muscle } \\
\text { with respect to the trunk } \\
\text { Nephridia extent }\end{array}$ & 7 & $4-5$ & $7-8$ \\
$\begin{array}{c}\text { Longitude of basal spinelets } \\
\text { longer than } \\
\text { principal tooth }\end{array}$ & $\begin{array}{c}<50 \% \text { of trunk } \\
\text { shorter than } \\
\text { principal tooth }\end{array}$ & $\begin{array}{c}80 \% \text { of trunk } \\
\text { longer than } \\
\text { principal tooth }\end{array}$ \\
\hline
\end{tabular}

\title{
Remarks
}

We reinstate the name Phascolosoma hespera in the correct genus as the new combination Apionsoma (Apionsoma) hespera. The most similar species to $A$. (A.) hespera comb. nov. is $A$. (A.) misakianum (Ikeda, 1904) from Misaki, Japan (Table 4). Fisher (1952) illustrated type material and he showed the morphological and ecological differences between the two species. Cutler (1979) considered Phascolosoma hespera Chamberlin, 1920 and Golfingia hespera sensu Fisher 1952 as synonyms of $A$. (A.) misakianum, but we believe that the morphological features are enough to consider $P$. hespera as a valid name with a distribution in the TEP. We compared the illustrations of the hooks of A. (A.) misakinaum, from Misaki (Ikeda 1904; Fig. 8D) and other localities of Japan (Cutler et al. 1984: 300-301; Fig. 8E), with the hooks of the specimens revised in this study (Fig. 8A) and those of specimens recorded from Peru as Golfingia (Mitosiphon) hespera (Amor 1975; Fig. 8B-C). Staton \& Rice (1999) stated that there is strong reproductive isolation between the northern and southern populations of the A. misakianum species complex, another argument to consider that $A$. hespera is a valid species and likely could be part of this species complex.

\section{Habitat}

Intertidal, in Cerianthus tubes, in rocks with Phragmatopoma and Perumytilus.

\section{Distribution}

Laguna Beach, California; Tropical Eastern Pacific from Baja California Sur to Oaxaca; Ancón, Peru.

\author{
Subgenus Apionsoma (Edmondsius) Gibbs \& Cutler, 1987
}

Apionsoma (Edmondsius) pectinatum (Keferstein, 1867)

Fig. 10

Phascolosoma pectinatum Keferstein, 1867: 47-48 (type locality: Pacific of Panama).

Siphonides rickettsi Fisher, 1952: 386-388, pl. 22 (type locality: near La Paz, Baja California, Mexico, under boulders).

Phascolosoma (Satonus) pectinatum - E. Cutler 1977: 150 (from Gulf of Panama, Panama). 


\section{Material examined}

MEXICO • 21; Oaxaca, Zipolite; 15³9'37" N, 96³0'38" W; 16 Nov. 2016; FRE leg.; depth 2 m, in dead coral; UMAR-SIPU 011 • 8; Huatulco, San Agustín Bay; 1541'21" N, 96¹4'11" W; 17 Nov. 2016; JGV leg.; depth $2 \mathrm{~m}$, in dead coral; UMAR-SIPU 012.


Fig. 10. Apionsoma (Edmondsius) pectinatum (Keferstein, 1867) from the Southern Mexican Pacific. A. Internal morphology. B. External morphology. C. Hook. Abbreviations: I = intestine; LMB = longitudinal muscle bands; $\mathrm{N}=$ nephridium; $\mathrm{RM}=$ retractor muscles. 


\section{Description}

Trunk $20 \mathrm{~mm}$ in length (Fig. 10A). Trunk light yellowish to dark brown in color, with dome-shaped papillae around trunk and base of introvert, scattered on body. Body wall wrinkled, giving a rough appearance (Fig. 10B). Introvert 2-4 times as long as trunk. Tentacles digitiform, encircling nuchal organ. Thirty rings of hooks in anterior region of introvert, with seven basal spinelets (Fig. 10C). Two pairs of retractor muscles. A pair of bilobed nephridia. Longitudinal bands of body wall show slight anastomosis. Nephridia with $40 \%$ of trunk length. Spindle muscle not attached to posterior end of trunk (Fig. 10A).

\section{Remarks}

With only a few records at the time, Cutler (1994) concluded that the distribution of Apionsoma (Edmondsius) pectinatum in the Eastern Pacific went from Baja California to Panama, so its distribution in the rest of TEP could only be inferred. This new record from the Southern Mexican Pacific breaks the disjunctive distribution in the Tropical Eastern Pacific for this species.

\section{Habitat}

Subtidal (2 m); in dead coral.

\section{Distribution}

Tropical Eastern Pacific, from Baja California Sur, Mexico to Gulf of Panama.

Family Aspidosiphonidae Baird, 1868

Genus Aspidosiphon Diesing, 1851

Subgenus Aspidosiphon (Aspidosiphon) Diesing, 1851

Aspidosiphon (Aspidosiphon) elegans (Chamisso \& Eysenhardt, 1821)

Fig. 11

Sternaspis elegans Chamisso \& Eysenhardt, 1821: 351-352, pl. 24, fig. 5a-e (type locality: Radack, Marshall Islands).

\section{Material examined}

MEXICO - Guerrero • 14; Ixtapa Island, Coral Beach; 17040'37" N, 101³9'20" W; 19 Sep. 2007;


30 Apr. 2005; UMAR-SIPU $074 \bullet 1$; same locality as for preceding but 12 Sep. 2006; UMAR-SIPU 078 •

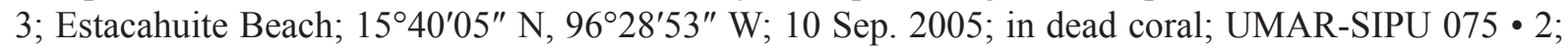
same locality as for preceding but 20 Sep. 2005; in dead coral; UMAR-SIPU 076 • 5; same locality as for preceding but 15 Aug. 2006; depth $4 \mathrm{~m}$, in dead coral; UMAR-SIPU 077 - 2; Chachacual Bay, Jicaral Beach; 1542'39" N, 96 $12^{\prime} 11^{\prime \prime}$ W; 10 Feb. 2007; depth $6.1 \mathrm{~m}$, in Porites sp.; UMAR-SIPU $079 \bullet$ 5; Panteón Beach; 15³9'50" N, 96 29'42" W; 16 Apr. 2008; JDG and GGG leg.; depth 3 m, in dead

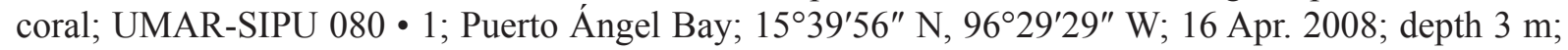
UMAR-SIPU-081.

\section{Comparative material}

MEXICO - Quintana Roo - 1; Xahuayxol; 26 Sep. 1996; ECOSUR-S0121 • 1; Contoy Island, Punta Sur; 2 Mar. 2001; in dead coral; ECOSUR-S0124 • 1; Mahahual; 22 Mar. 2000; in dead coral; ECOSUR-S0128 • 3; Nizuc; 30 Aug. 1999; depth 2.2 m, in rock with Dyctiota; ECOSUR-S0129. 


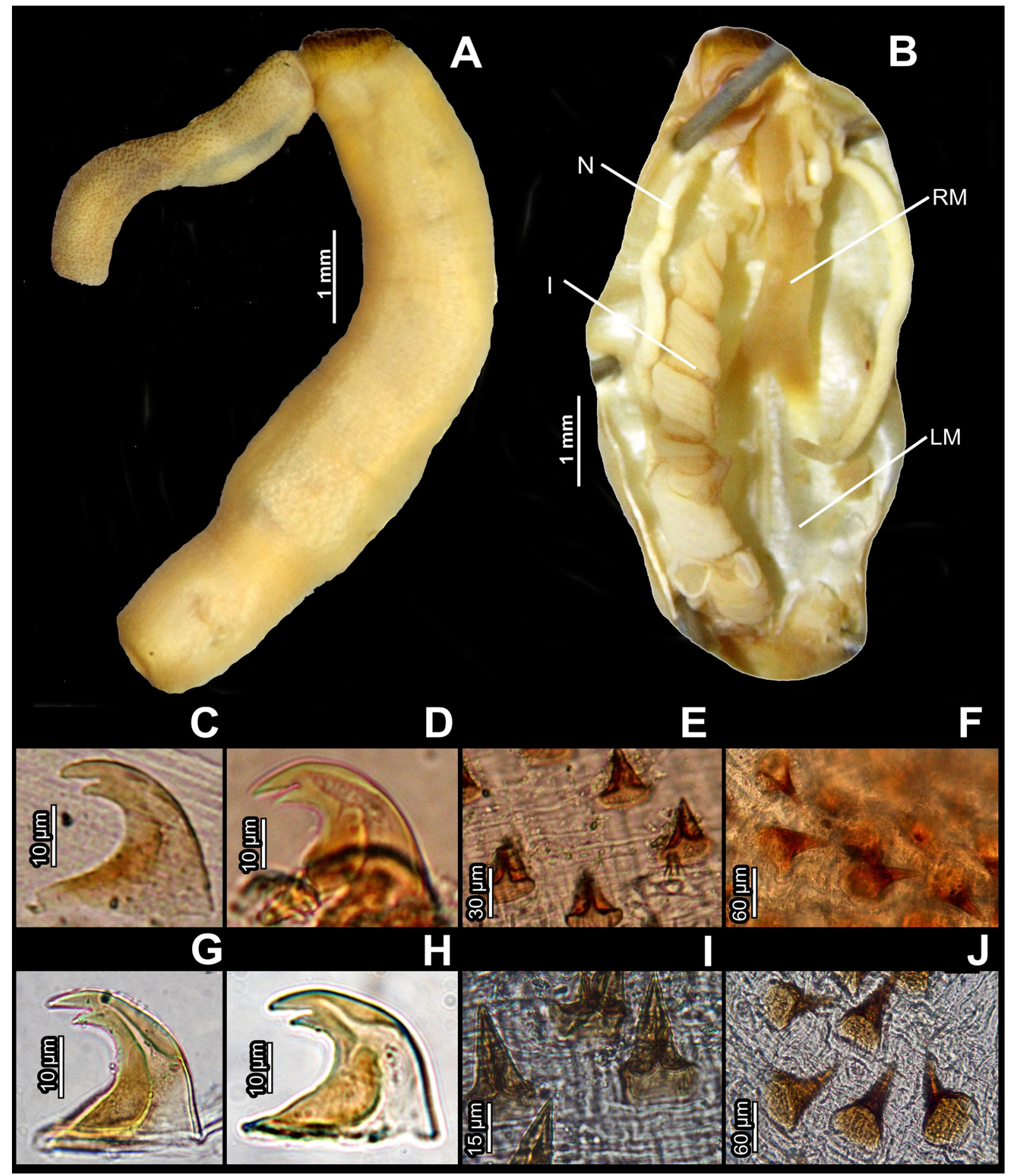

Fig. 11. Aspidosiphon (Aspidosiphon) elegans (Chamisso \& Eysenhardt, 1821). A-F. From the Southern Mexican Pacific. A. External morphology. B. Internal morphology. C. Bidentate hooks of proximal rings. D. Bidentate hooks of distal rings. E. Anterior conical hooks. F. Posterior conical hooks. G-J. From the Mexican Caribbean. G. Bidentate hooks of proximal rings. H. Bidentate hooks of distal rings. I. Anterior conical hooks. J. Posterior conical hooks. Abbreviations: I $=$ intestine; LM = longitudinal muscle; $\mathrm{N}=$ nephridium; $\mathrm{RM}=$ retractor muscles. 


\section{Description}

Trunk $8 \mathrm{~mm}$ in length, white (Fig. 11A). Introvert three times the trunk length. Anal shield without grooves, caudal shield absent. Fourteen rings of bidentate compressed hooks (Fig. 11C-D) followed by scattered unidentate, dark, conical hooks (Fig. 11E-F). Longitudinal muscle of body wall in uniform continuous layer. A pair of retractor muscles originate at about $50 \%$ of trunk length. A pair of nephridia, unilobed, at $60 \%$ of trunk length. Spindle muscle attached posteriorly (Fig. 11B).

\section{Remarks}

The original description by Chamisso \& Eysenhardt (1821) did not include a description of the hooks; thus, we cannot compare our specimens with the original description. Nevertheless, a revision is necessary because it is likely that the population of the Marshall Islands is different from the one of the SMP. This species has been recorded from Cocos Island, Costa Rica (Dean et al. 2010). We did not find differences between the species in the SMP and the Mexican Caribbean (Fig. 11G-J).

\section{Habitat}

Intertidal to subtidal (4 m); in algae and dead coral (Porites).

\section{Distribution}

Widespread and common in the Indian and western Pacific Oceans, from south-central Japan to northern Australia to Hawaii, the Red Sea, and Israel. In the Caribbean from northern Brazil to the Florida Keys and Bermuda (Cutler 1994). In the Eastern Pacific from the South Mexican Pacific to Costa Rica (Fonseca \& Cortés 1998; Dean et al. 2010).

\section{Subgenus Aspidosiphon (Paraspidosiphon) Stephen, 1965}

Aspidosiphon (Paraspidosiphon) cutleri sp. nov. urn:lsid:zoobank.org:act:48C0AFB4-02DD-4164-9223-BDA2CC1D0A43

Fig. 12

\section{Etymology}

In memory of Edward Cutler, expert in sipunculans and the principal source of inspiration for this work.

\section{Material examined}

\section{Holotype}

MEXICO • Oaxaca, Camarón Beach; 15³9'45" N, 96³1'33" W; 6 Apr. 2013; in dead coral; RXP and VAR leg.; UMAR-SIPU 082.

\section{Paratypes}

MEXICO • 1; same locality as for holotype; 16 Nov. 2016; JGV leg.; depth $2 \mathrm{~m}$, in rocks, UMAR-SIPU 083 - 1; Oaxaca, San Agustin Bay; 1541'21.1" N, 96²14'11.1" W; 18 Mar. 2018; depth 2 m, in rocks; UMAR-SIPU 107.

\section{Description}

Trunk $30 \mathrm{~mm}$ in length, white (Fig. 12A). Anal and caudal shield brown. Sixteen longitudinal grooves in anal shield. Caudal shield also with grooves (Fig. 12C-D). Units of anal region distributed in longitudinal lines (Fig. 12E). More than 100 rings of unidentate proximal hooks, smaller than distal hooks (Fig. 12F) followed by scattered pyramidal hooks. Longitudinal muscles of body wall gathered into anastomosing bands. A pair of retractor muscles, fused for most of their length. Nephridia unilobed, occupying $50 \%$ of the trunk. Spindle muscle bifurcated near its anterior end (Fig. 12B). 


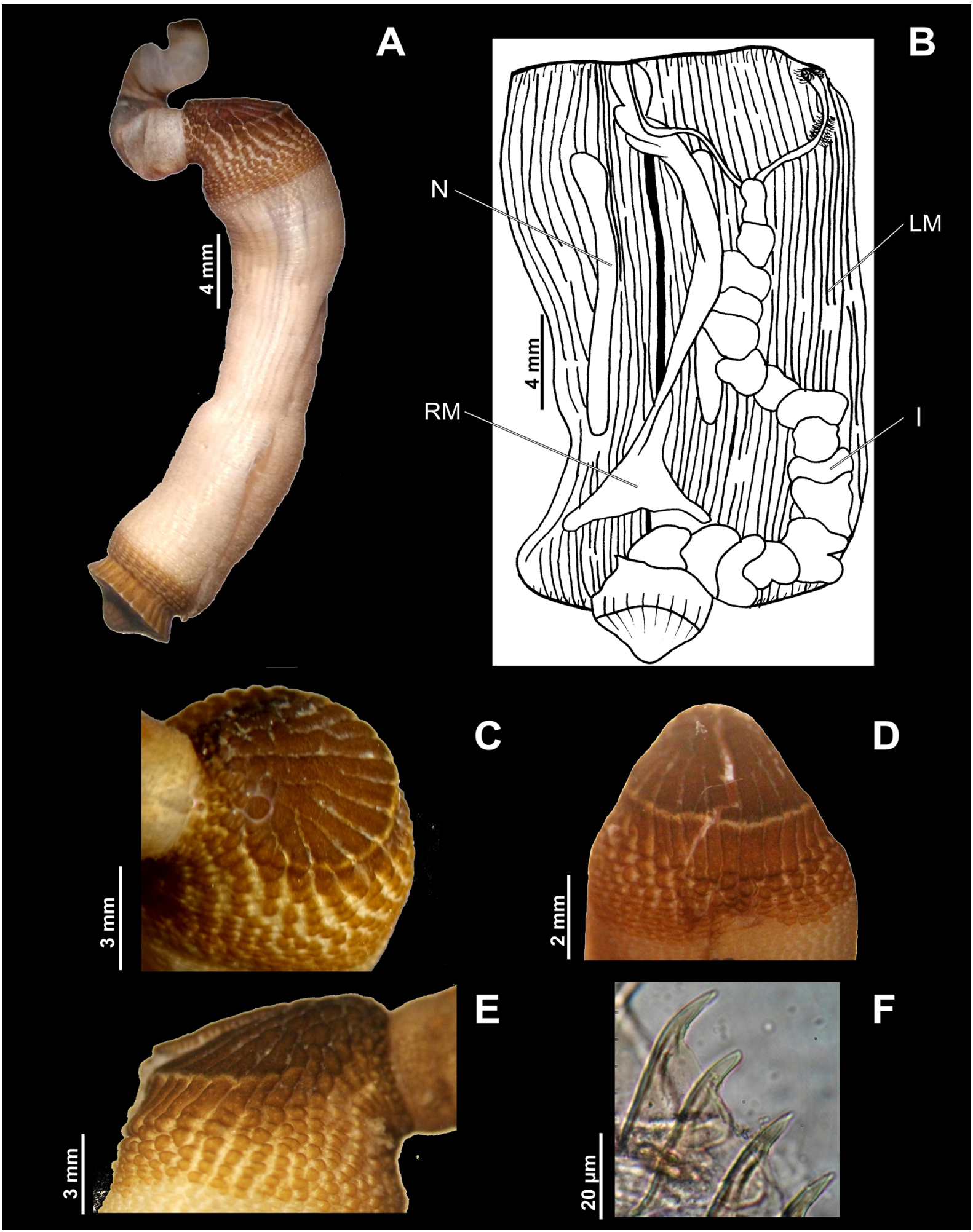

Fig. 12. Aspidosiphon (Aspidosiphon) cutleri sp. nov., holotype (UMAR-SIPU 082), from the Southern Mexican Pacific. A. External morphology. B. Internal morphology. C. Anal shield, dorsolateral view. D. Anal shield, dorsal view. E. Anal shield, lateral view. F. Distal unidentate hooks. Abbreviations: I = intestine; $\mathrm{LM}=$ longitudinal muscle; $\mathrm{N}=$ nephridium; $\mathrm{RM}=$ retractor muscles. 


\section{Remarks}

The species that are most similar to Aspidosiphon (Paraspidosiphon) cutleri sp. nov. are A. (P.) coyi de Quatrefages, 1865, described from the Indian Ocean, and A. (P.) laevis de Quatrefages, 1865. The type material of these two species was described by Saiz-Salinas (1983). The main differences between these species are the following: Aspidosiphon (P.) coyi has bidentate hooks and disperse units in the anterior region of the trunk; Aspidosiphon laevis lacks bidentate hooks and the units on the anterior region of the trunk are dispersed; nephridiopores are at the same level as the anus in both these species; on the other hand, A. (P.) cutleri sp. nov. only has unidentate hooks and the units are distributed in lines on the anterior region of the trunk; the nephridiopores are posterior to the anus. It is likely that the record of A. (P.) laevis from Costa Rica (Dean et al. 2010) corresponds to this new species; however, it is necessary to review the specimens.

\section{Habitat}

Subtidal (2 m); in dead coral.

\section{Distribution}

Oaxaca, Mexico.

Aspidosiphon (Paraspidosiphon) pastori sp. nov. urn:lsid:zoobank.org:act:F0F14077-9BB9-439E-AE38-A9EE4BEA0CBA

Fig. 13A-F

\section{Etymology}

This new species was named as "pastori" after Mr Pastor Silva Cruz, for his invaluable support and inspiration to work in the field of marine science.

\section{Material examined}

\section{Holotype}

MEXICO • Oaxaca, Panteón Beach; 15³9'50.8" N, 96²9'42.4" W; 28 Apr. 2012; NHH and KLT leg.; in rocks; UMAR-SIPU 128.

\section{Paratypes}

MEXICO - Oaxaca • 1; same collection data as for holotype; UMAR-SIPU $099 \cdot 2$; Panteón Beach; 1539'50" N, 96²9'42" W; 30 Mar. 2017; JGV leg.; depth 2 m, in dead coral; UMAR-SIPU 100.

\section{Other material}

MEXICO - Guerrero • 7; Ixtapa Island, Coral Beach; 19 Sep. 2007; SGM leg.; in dead coral; UMARSIPU 084 • 1; Acapulco, Roqueta Island; 21 Sep. 2007; SGM leg.; in sponge; UMAR-SIPU 085 • 1; Barra de Potosí; 3 Dec. 2010; UMAR-SIPU 086. - Oaxaca • 1; La Entrega Beach; Aug. 2004; SGM leg.; in Spondylus limbatus G.B. Sowerby II, 1847; UMAR-SIPU 087 • 1; Estacahuite Beach; 18 Apr. 2005; SGM leg.; in dead coral; UMAR-SIPU 088 • 3; Estacahuite Beach; 30 Apr. 2005; in dead coral; UMAR-SIPU 089 • 13; Estacahuite Beach; 10 Sep. 2005; SGM leg.; in dead coral; UMAR-SIPU 090 - 1; Estacahuite Beach; 15 Aug. 2006; depth 4 m, in dead coral; UMAR-SIPU 091 • La Tijera Beach; 12 Sep. 2006; depth 4 m, in dead coral, UMAR-SIPU 092 -2; Chacahua; 14 Apr. 2007; SGM leg.; in artificial monticule; UMAR-SIPU 094 • 1; Chacahua; 3 Apr. 2008; in rocks; UMAR-SIPU 095 • 2; Panteón Beach; 21 May 2008; MLY leg.; depth 3 m, in rocks; UMAR-SIPU 096 • 1; La Tijera Beach; 6 May 2009; in rocks; UMAR-SIPU 097 • 2; Salchi Beach; 26 March 2010; depth 7 m; UMAR-SIPU 098.

\section{Description}

Trunk $10 \mathrm{~mm}$ in length, smooth and thin (Fig. 13A). Anal and caudal shields yellow, introvert light brown and trunk white (Fig. 13C). Introvert two times as long as trunk. Rings of compressed, bidentate 


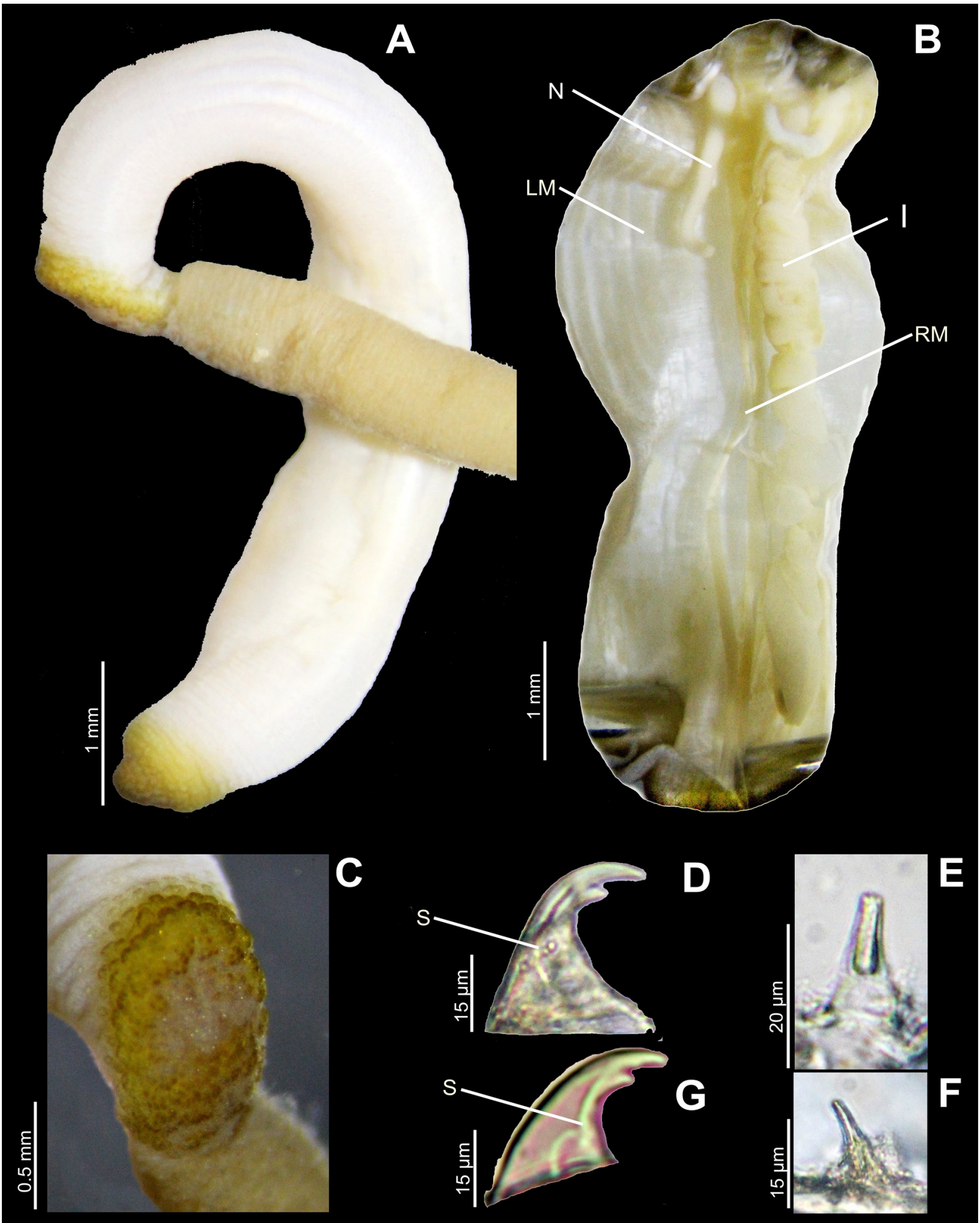

Fig. 13. - A-F. Aspidosiphon (Paraspidosiphon) pastori sp. nov., holotype (UMAR-SIPU 128). A. External morphology. B. Internal morphology. C. Anal shield. D. Bidentate hook. E. Papillae from introvert. F. Pyramidal hook. - G. Bidentate hook of A. (P.) fischeri ten Broeke, 1925 from the Mexican Caribbean. Abbreviations: $\mathrm{I}=$ intestine; $\mathrm{LM}=$ longitudinal muscle; $\mathrm{N}=$ nephridium; $\mathrm{RM}=$ retractor muscles; $\mathrm{S}=$ streak. 
hooks, some hooks unidentate (Fig. 13D), followed by scattered and pyramidal hooks (Fig. 13F). Papillae present on entire introvert (Fig. 13E). Bidentate hooks with the streak oblique. Fifteen illdefined anastomosed muscle bands. Two retractor muscles fused at $75 \%$ of trunk length and occupying $90 \%$ of trunk. Nephridia occupying 30\% of trunk length, open posteriorly to anus (Fig. 13B).

\section{Remarks}

The species that is most similar to Aspidosiphon (Paraspidosiphon) pastori sp. nov. is A. (P.) fischeri (ten Broeke, 1925) from Caracas Bay, Venezuela; however, they are different in the shape of the hooks and the longitudinal muscle bands. Aspidosiphon (Paraspidosiphon) pastori sp. nov. has hooks with an oblique streak, while $A$. fischeri has hooks with a straight streak (Fig. 13G). Aspidosiphon (Paraspidosiphon) pastori sp. nov. has 14-16 longitudinal muscle bands, while A. fischeri has 18-19 LMB.

\section{Habitat}

Intertidal to subtidal (7 m); in dead coral, sponges, bivalves and rocks.

\section{Distribution}

South Mexican Pacific, from Ixtapa Island, Guerrero, to La Entrega Beach, Oaxaca.

\section{Identification key to all families from the Tropical Eastern Pacific (modified from Cutler 1994)}

1. Tentacles encircling the mouth (peripheral tentacles); hooks, when present, are scattered ......2

- Tentacles encircling the nuchal organ (nuchal tentacles), peripheral tentacles absent; hooks, if present, arranged in rings

2. Longitudinal muscles of body wall in uniform continuous layer Golfingiidae

- Longitudinal muscles of body wall gathered into separate or anastomosing bands .3

3. Longitudinal and circular musculature with anastomosis; spindle muscle attached to the posterior trunk Siphonosomatidae

- Longitudinal and circular musculature in continuous bands; spindle muscle not attached to the posterior trunk Sipunculidae

4. Hooks absent; contractile vessel with villi

.Antillesomatidae (Antillesoma mexicanum Silva-Morales et al., $2019^{1}$ )

- Hooks present; contractile vessel without villi

5. Anal shield present Aspidosiphonidae

- Anal shield absent Phascolosomatidae

${ }^{1}$ This species is separate from Antillesoma antillarum (Grube, 1859) because of differences in the length of the organisms and for the molecular divergences noted by Silva-Morales et al. (2019).

\section{Identification keys to all species of sipunculans from the Tropical Eastern Pacific}

\section{Family Aspidosiphonidae}

1. Hooks, if present, not in rings Aspidosiphon (Akrikos) albus Murina, 1967

- Hooks in rings on the distal region of the introvert

2. Longitudinal muscle layer divided into separate (or anastomosing) bundles Aspidosiphon (Paraspidosiphon).........3

- Longitudinal muscles in continuous layer (except under anal shield) .Aspidosiphon (Aspidosiphon).........7 




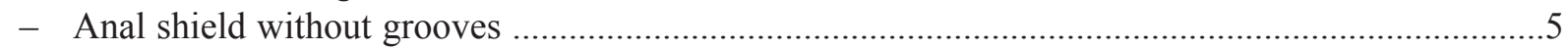

4. Papillae of anterior trunk scattered .....Aspidosiphon (Paraspidosiphon) laevis de Quatrefages, 1865

- Papillae of anterior trunk in lines ............................Aspidosiphon (Paraspidosiphon) cutleri sp. nov.

5. Compressed hooks bidentate, followed by dark pyramidal hooks

Aspidosiphon (Paraspidosiphon) steenstrupii Diesing, 1859

- Compressed hooks bidentate, followed by pale pyramidal hooks .................................................6

6. Hooks bidentate, with streak vertical on the superior region

Aspidosiphon (Paraspidosiphon) fischeri ten Broeke, 1925

- Hooks bidentate, with streak oblique on the superior region

Aspidosiphon (Paraspidosiphon) pastori sp. nov.

7. Individual units form into longitudinal ridges over dorsal half of anal shield Aspidosiphon (Aspidosiphon) muelleri Diesing, 1851

- Without individual units that form into longitudinal ridges over dorsal half of anal shield .........8

8. All hooks unidentate; ill-defined anal shield

Aspidosiphon (Aspidosiphon) gracilis schnehageni Fischer, 1912

- Distal hooks bidentate; anal shield well-defined

9. All compressed hooks bidentate, followed by dark conical hooks

Aspidosiphon (Aspidosiphon) elegans (Chamisso \& Eysenhardt, 1821)

- Distal bidentate compressed hooks, followed by proximal unidentate ones

10. Gut helicoidal; lives in gastropod shells; anal shield units not tightly packed and of similar size Aspidosiphon (Aspidosiphon) gosnoldi Cutler, 1981

- Gut coils loose or absent; does not occupy gastropod shells; anal shield more solid, with closeset, granular units of differing sizes Aspidosiphon (Aspidosiphon) misakiensis Ikeda, 1904

\section{Family Golfingiidae}

1. Branched tentacles carried on four to eight stem-like outgrowths of oral disk ........Themiste........2

- Tentacles not carried on stem-like outgrowths 3

2. Hooks present Themiste (Themiste) pyroides (Chamberlin, 1919)

- Hooks absent Themiste (Themiste) hennahi Gray, 1828

3. Two nephridia .Nephasoma ........4

- One nephridium

4. Hooks present Nephasoma (Nephasoma) pellucidum pellucidum (Keferstein, 1865)

- Hooks absent ...Nephasoma (Nephasoma) elachea (Fisher, 1952)

5. Anus usually located on anterior trunk; epidermal holdfast or attachment papillae often present; retractor muscles highly fused but usually with 2-4 origin points Phascolion........6

- Anus situated on distal half of introvert; epidermal attachment papillae absent; retractor muscles appear as single column, without separate origin points Onchnesoma ....7

6. Tentacles reduced to lobes at the end of the introvert, which is about equal in length to the trunk

- 10-30 well-developed tentacles usually present

.Phascolion (Montuga) pacificum Murina, 1957

Phascolion (Phascolion) strombus (Montagu, 1804) 
7. Cylindrical body, without papillae Onchnesoma magnibathum Cutler, 1969

- Spherical or pear-shaped body, with papillae

Onchnesoma steenstrupii steenstrupii Koren \& Danielssen, 1876

\section{Family Phascolosomatidae}

1. Introvert much longer than twice the trunk length; hooks, if present, with basal spinelets; nephridia usually bilobed Apionsoma........2

- Introvert less than twice trunk length; hooks without basal spinelets; nephridia unilobed .Phascolosoma.........4

2. Body wall muscles divided into separate bands

- Body wall with continuous muscle layers

Apionsoma (Edmonsius) pectinatum (Keferstein, 1867)

3. Papillae, hooks and tentacles absent Apionsoma (Apionsoma).........3

- Papillae, hooks and tentacles present, 7-8 basal spinelets

Apionsoma (Apionsoma) hespera (Chamberlin, 1920) comb. nov.

4. Protuberance of the hook streak less than twice the width of the hook

Phascolosoma (Phascolosoma) puntarenae Grube \& Örsted in Grube, 1858

- Hook without protuberance of the hook streak

5. Hook triangle indistinct or absent; preanal papillae not distinct from dome-shaped trunk papillae ..Phascolosoma (Phascolosoma) agassizii Keferstein, 1866

- Hook triangle well-defined; preanal papillae distinct

6. Preanal papillae dome- to mammiform-shaped at the base of the introvert

..Phascolosoma (Phascolosoma) scolops (Selenka \& de Man in Selenka, 1883)

- Preanal papillae conical, posteriorly directed on the dorsal base of the introvert

Phascolosoma (Phascolosoma) perlucens Baird, 1868

Family Sipunculidae

1. With a pair of protractor muscles

Xenosiphon branchiatus (Fischer, 1894)

- Protractor muscles absent Sipunculus.

2. With 42 or more LMB; digitate processes of the brain present

Sipunculus (Sipunculus) cf. polymyotus Fisher, 1947

- With 41 or less LMB; digitate processes of the brain absent .3

3. With 34 or less LMB; nephridia partially attached

- With 35-41 LMB; nephridia unattached

Sipunculus (Sipunculus) nudus Linnaeus, 1766 Sipunculus (Sipunculus) phalloides phalloides (Pallas, 1774)

\section{Family Siphonosomatidae}

1. Rectum with multiple rectal caecae or diverticulae

Siphonosoma cf. vastum (Selenka \& Bülow in Selenka, 1883)

- Rectum without multiple rectal caecae or diverticulae and dorsal retractor muscles originate anterior to ventral pair Siphonosoma cumanense (Keferstein, 1867) 


\section{Discussion}

The taxonomy of Sipuncula remains complicated. There are too few morphological characters to easily separate species. The study of sipunculans requires caution when reviewing records of species from any locality. Cutler (1994) produced a list of 150 species, most of those cosmopolitan or of wide distribution, and a long list of synonyms. This led to cases of specimens from far distant populations being assigned the same name. For example, Dean (2001), Dean et al. (2010) and Hermoso-Salazar et al. (2013) recorded some species from Pacific Costa Rica and Mexico with names from Europe, the Indian Ocean, Western Pacific and Caribbean. The idea that most marine invertebrates have wide distributions has been questioned recently (Hutchings \& Kupriyanova 2018). Regarding sipunculans, there are many studies rejecting these wide distributions, supported by careful morphological and molecular investigations (Staton \& Rice 1999; Kawauchi \& Giribet 2010, 2014; Schulze et al. 2012; Johnson et al. 2016; SilvaMorales et al. 2019; Silva-Morales 2020).

The importance of being cautious implies giving due importance to the type locality in the records of species. In this study, the records of Themiste (T.) hennahi and Apionsoma (Edmonsius) pectinatum were based on the correspondence of the diagnostic characters with the original description and the proximity of the type locality with the sample locality. In the case of Aspidosiphon (A.) elegans we recorded the nominal species; nevertheless, we suggest other types of studies to confirm or reject this wide distribution because we did not find any morphological distinction. With Siphonosoma cf. vastum, Sipunculus $(S$.) cf. polymyotus and Phascolosoma (P.) cf. perlucens we found morphological differences or molecular data to consider them "confer" and not the nominal species; the possibility remains that these could be new species for the tropical eastern Pacific. On the other hand, two names were reestablished: Apionsoma (A.) hespera comb. nov. and Phascolosoma (P.) puntarenae. For similar cases we suggest reviewing the 320 previously existing species names (e.g., Stephen \& Edmonds 1972), because other valid names could be buried in the synonyms of presumed widely distributed species. The new species, Aspidosiphon (P.) cutleri sp. nov. and A. (P.) pastori sp. nov. can be easily separated from the others of the same genus and subgenus by observing the internal characteristics of the hooks and the longitudinal muscle bands.

This study is the first work about sipunculans in the Southern Mexican Pacific, more than $1000 \mathrm{~km}$ of coastline for which no records of this phylum existed (Bastida-Zavala et al. 2013). This work will improve our knowledge of the sipunculans in the Tropical Eastern Pacific because it gathers information that was scattered, with a commented list and an identification key to help future studies.

\section{Acknowledgements}

The authors gratefully acknowledge the support of the project "Evaluación del potencial de las técnicas de Secuencia masiva, ADN ambiental y Código de barras genético para la descripción de la biodiversidad bentónica de los ecosistemas marinos y costeros de Oaxaca" (Conacyt 2015-01-1408). Thanks to Luis Fernando Carrera-Parra (ECOSUR) for providing the specimens from the Mexican Caribbean for comparison. Thanks to J. Rolando Bastida-Zavala (Universidad del Mar) by the critical revision of a previous version of this paper. Thanks to Gisele Yukimi Kawauchi (Federal University of Minas Gerais, Brazil) for her revisions and comments to improve this manuscript. Finally, thanks to Gerardo FloresTaboada for his English revision. Thanks to both anonymous reviewers for their suggestions to improve this manuscript.

\section{References}

Amor A. 1975. Notas sobre Sipuncula de la Argentina, Brasil y Perú. Physys 34: 113-120.

Baird W.B. 1868. Monograph of the species of worms belonging to the subclass Gephyrea. Proceedings of the Zoological Society of London 1868: 77-114. 
Bastida-Zavala J.R., García-Madrigal M.S., Rosas-Alquicira E.F., López-Pérez R.A., Benítez-Villalobos F., Meraz-Hernando J.F., Torres-Huerta A.M., Montoya-Márquez A. \& Barrientos-Luján N.A. 2013. Marine and coastal biodiversity of Oaxaca, Mexico. Check List 9: 329-390.

https://doi.org/10.15560/9.2.329

Berrú P.M. \& Berrú M.A. 2013. Sipunculus nudus (Linnaeus, 1769). Primer registro para la region Áncash y el Perú (Sipuncula, Sipunculidae). Cientifica 10: 245-252.

https://doi.org/10.21142/cient.v10i3.221

Broeke J.M.A. ten. 1925. Westindische Sipunculiden und Echiuriden. Bijdragen tot de Dierkunde 24: 81-96. https://doi.org/10.1163/26660644-02401006

Brusca R.C. 1980. Common Intertidal Invertebrates of the Gulf of California. The University of Arizona Press, Tucson.

Brusca R.C. \& Thompson D.A. 1977. Pulmo Reef: the only "coral reef" in the Gulf of California. Ciencias Marinas 2: 37-53. https://doi.org/10.7773/cm.v2i2.290

Cantera J.R.K., Orozco C., Londoño-Cruz E. \& Toro-Farmer G. 2003. Abundance and distribution patterns of infaunal associates and macroborers of the branched coral (Pocillopora damicornis) in Gorgona Island (Eastern Tropical Pacific). Bulletin of Marine Science 72: 207-219.

Chamberlin R.V. 1920. Notes on the sipunculids of Laguna Beach. Journal of Entomology and Zoology 12: $30-31$.

Chamisso A. \& Eysenhardt C.G. 1821. De animalibus quisbusdam e classe vermium linneana. Nova Acta Academia Caesarea Leopoldino 10: 343-374.

Cutler E.B. 1969. New species of Sipuncula from the western North Atlantic. Proceedings of the Biological Society of Washington 82 (1): 209-218.

Available from https://www.biodiversitylibrary.org/page/34595222 [accessed 4 Mar. 2021].

Cutler E.B. 1977. The bathyal and abyssal Sipuncula. Galathea Report 14: 135-156.

Cutler E.B. 1979. A reconsideration of the Golfingia subgenera Fisherana Stephen, Mitosiphon Fisher, and Apionsoma Sluiter (Sipuncula). Zoological Journal of the Linnean Society 65: 367-384.

https://doi.org/10.1111/j.1096-3642.1979.tb01101.x

Cutler E.B. 1981. A new species of Aspidosiphon (Sipuncula) from the western Atlantic Ocean. Proceedings of the Biological Society of Washington 94 (2): 445-449.

Available from https://www.biodiversitylibrary.org/page/34608302 [accessed 4 Mar. 2021].

Cutler E.B. 1994. The Sipuncula: their Systematics, Biology and Evolution. Cornell University, New York. https://doi.org/10.2307/2413618

Cutler E.B. \& Cutler N.J. 1980. Sipuncula collected by the R/V "Vema". Journal of Zoology 190: 193-209. https://doi.org/10.1111/j.1469-7998.1980.tb07766.x

Cutler E.B. \& Cutler N.J. 1982. A revision of the genus Siphonosoma (Sipuncula). Proceedings of the Biological Society of Washington 95 (4): 748-762.

Available from https://www.biodiversitylibrary.org/page/34965066 [accessed 2 Mar. 2021].

Cutler E.B. \& Cutler N.J. 1983. An examination of the Phascolosoma subgenera Antillesoma, Rueppellisoma, and Satonus (Sipuncula). Zoological Journal of the Linnean Society 77 (2): 175-187. https://doi.org/10.1111/j.1096-3642.1983.tb00528.x

Cutler E.B. \& Cutler N.J. 1985a. A revision of the genera Sipunculus and Xenosiphon (Sipuncula). Zoological Journal of the Linnean Society 85 (3): 219-246.

https://doi.org/10.1111/j.1096-3642.1985.tb01504.x 
Cutler E.B. \& Cutler N.J. 1985b. A revision of the genera Phascolion Théel and Ochnesoma Koren and Danielssen (Sipuncula). Proceedings of the Biological Society of Washington 98 (4): 809-850. Available from https://www.biodiversitylibrary.org/page/34649098 [accessed 2 Mar. 2021].

Cutler E.B. \& Cutler N.J. 1987. A revision of the genus Golfingia (Sipuncula: Golfingiidae). Proceedings of the Biological Society of Washington 100 (4): 735-761.

Available from https://www.biodiversitylibrary.org/page/34644022 [accessed 2 Mar. 2021].

Cutler E.B. \& Cutler N.J. 1988. A revision of the genus Themiste (Sipuncula). Proceedings of the Biological Society of Washington 101 (4): 741-766.

Available from https://www.biodiversitylibrary.org/page/34646438 [accessed 2 Mar. 2021].

Cutler E.B. \& Cutler N.J. 1989. A revision of the genus Aspidosiphon (Sipuncula, Aspidosiphonidae). Proceedings of the Biological Society of Washington 102 (4): 826-865.

Available from https://www.biodiversitylibrary.org/page/34551216 [accessed 2 Mar. 2021].

Cutler E.B. \& Gibbs P.E. 1985. A phylogenetic analysis of higher taxa in the phylum Sipuncula. Systematic Zoology 34: 162-173. https://doi.org/10.2307/2413324

Cutler E.B., Cutler N.J. \& Nishikawa T. 1984. The Sipuncula of Japan: their systematics and distribution. Publications of the Seto Marine Biological Laboratory 29 (4/6): 249-322.

Cutler N.J. \& Cutler E.B. 1986. A revision of the genus Nephasoma (Sipuncula: Golfingiidae). Proceedings of the Biological Society of Washington 99 (4): 547-573.

Available from https://www.biodiversitylibrary.org/page/34596022 [accessed 2 Mar. 2021].

Cutler N.J. \& Cutler E.B. 1990. A revision of the subgenus Phascolosoma (Sipuncula: Phascolosoma). Proceedings of the Biological Society of Washington 103: 691-730.

Available from https://www.biodiversitylibrary.org/page/34592152 [accessed 2 Mar. 2021].

Cutler N.J., Cutler E.B. \& Vargas J.A. 1992. Peanut worms (Phylum Sipuncula) from Costa Rica. Revista de Biología tropical 40: 153-158.

Dean H.K. 2001 Marine biodiversity of Costa Rica: The phyla Sipuncula and Echiura. Revista de Biología tropical 2: 85-90.

Dean H.K., Sibaja-Cordero J.A., Cortés J., Vargas R. \& Kawauchi G.Y. 2010. Sipunculans and echiurans of Isla del Coco (Cocos Island), Costa Rica. Zootaxa 2557 (1): 60-68.

https://doi.org/10.11646/zootaxa.2557.1.6

Diesing K.M. 1851. Systema Helminthum. Braumüller, Vindobonae [Vienna].

Diesing K.M. 1859. Revision der Rhyngodeen. Sitzungsberichte der mathematisch-naturwissenschaftliche Klasse, Akademie der Wissenschaften in Wien 37: 719-782.

Dordel J., Fisse F., Purschke G. \& Struck T.H. 2010. Phylogenetic position of Sipuncula derived from multi-gene and phylogenomic data and its implication for the evolution of segmentation. Journal of Zoological Systematics and Evolutionary Research 48 (3): 197-207.

https://doi.org/10.1111/j.1439-0469.2010.00567.x

Fischer W. 1895 Die Gephyreen des Naturhistorischen Museums zu Hamburg. Abhandlungen aus dem Gebiet der Naturwissenschaften 13: 1-24.

Fischer W. 1913. Über einige Sipunculiden des Naturhistorischen Museums zu Hamburg. Jahrbuch der hamburgischen wissenschaftlichen Anstalten 30: 93-101.

Fisher W.K. 1947. New genera and species of echiuroid and sipunculoid worms. Proceedings of the United States National Museum 97 (3218): 351-372. https://doi.org/10.5479/si.00963801.97-3218.351 
SILVA-MORALES I. \& GÓMEZ-VÁSQUEZ J.D., Sipunculans from the Southern Mexican Pacific

Fisher W.K. 1952. The sipunculid worms of California and Baja California. Proceedings of the United States National Museum 102 (3306): 371-450. https://doi.org/10.5479/si.00963801.102-3306.371

Fisher W.K. 1954. A swimming Sipunculus. Annals and Magazine of Natural History (Series 12) 7 (75): 238-240. https://doi.org/10.1080/00222935408651722

Fonseca A.C. \& Cortés J. 1998. Coral borers of the Eastern Pacific: Aspidosiphon (A.) elegans (Sipuncula: Aspidosiphonidae) and Pomatogebia rugosa (Crustacea: Upogebiidae). Pacific Science 52: 170-175.

Fonseca A.C., Dean H.K. \& Cortés J. 2005. Non-colonial coral macro-borers as indicators of coral reef status in the south Pacific of Costa Rica. Revista de Biología tropical 54: 101-115.

https://doi.org/10.15517/rbt.v54i1.13977

Gibbs P.E. \& Cutler E.B. 1987. A classification of the phylum Sipuncula. Bulletin of the British Museum, Natural History 52: 43-58.

Gray J.E. 1828. Spicilegia Zoologica. Treuttel Wurtz \& Co., London.

Grube E. 1858. Annulata Örstediana, enumeratio annulatorum, quae in intinere per Indiam occidentalem et Americam centralem annis 1845-1848 suspecto legit cl. A.S. Örsted, adjectis speciebus nonnullis a cl. H. Kröyero in itinere ad Americam meriodinalem collectis. Videnskabelige Meddelelser fra dansk naturhistorisk Forening i Kjøbenhavn 1848: 105-120.

Hermoso-Salazar M., Frontana-Uribe S., Solís-Weiss V., Prol-Ledesma V.R.M. \& Estradas-Romero A. 2013. The occurrence of Sipuncula in the Wagner and Consag Basins, Northern Gulf of California. Cahiers de Biologie marine 54: 325-334.

Hutchings P. \& Kupriyanova E. 2018. Cosmopolitan polychaetes - fact or fiction? Personal and historical perspectives. Invertebrate Systematics 32 (1): 1-9. https://doi.org/10.1071/IS17035

Ikeda I. 1904. The Gephyrea of Japan. Journal of the College of Science, Imperial University of Tokyo 20: $1-87$.

Johnson N.D., Sanders C., Maiorova A. \& Schulze A. 2016. Cryptic species in Pacific sipunculans (Sipuncula: Phascolosomatidae): east-west divergence between non-sister taxa. Zoologica Scripta 45 (4): 455-463. https://doi.org/10.1111/zsc.12158

Kawauchi G.Y. \& Giribet G. 2010. Are there true cosmopolitan sipunculan worms? A genetic variation study within Phascolosoma perlucens (Sipuncula, Phascolosomatidae). Marine Biology 157: 14171431. https://doi.org/10.1007/s00227-010-1402-z

Kawauchi G.Y. \& Giribet G. 2014. Sipunculus nudus Linnaeus, 1766 (Sipuncula): Cosmopolitan or a group of pseudo-cryptic species? An integrated molecular and morphological approach. Marine Ecology 35 (4): 478-491. https://doi.org/10.1111/maec.12104

Kawauchi G.Y., Sharma P.P. \& Giribet G. 2012. Sipunculan phylogeny based on six genes, with a new classification and the descriptions of two new families. Zoologica Scripta 41 (2): 186-210.

https://doi.org/10.1111/j.1463-6409.2011.00507.x

Keferstein W. 1865. Beiträge zur anatomischen und systematischen Kenntniss der Sipunculiden. Zeitschrift für wissenschaftliche Zoologie 15: 404-445.

Keferstein W. 1866. Untersuchungen über einige amerikanische Sipunculiden. Nachrichten von der königlichen Gesellschaft der Wissenschaften und der Georg-Augusts Universität zu Göttigen 14: 215228.

Keferstein W. 1867. Untersuchungen über einige amerikanische Sipunculiden. Zeitschrift für Wissenschaftliche Zoologie 17: 44-55. 
Koren J. \& Danielssen D.C. 1875. Bidrag til de norske Gephyrea naturhistorie. Nytt Magasin for Naturvidenskaberne 21: 108-138.

Lemer S., Kawauchi G.Y., Andrade S.C.S., González V.L., Boyle M.J. \& Giribet G. 2015. Re-evaluating the phylogeny of Sipuncula through transcriptomics. Molecular Phylogenetics and Evolution 83: 174183. https://doi.org/10.1016/j.ympev.2014.10.019

Linnaeus C. 1766. Systema Naturae per Regna tria Naturce, secundum Classes, Ordines, Genera, Species, cum Charcteribus, Differentiis, Synonymis, Locis. Editio duodecima, reformata. Regnum animale. Laurentius Salvius, Holmiae [Stockholm].

Melwani A.R. \& Kim S.L. 2008. Benthic infaunal distributions in shallow hydrothermal vent sediments. Acta Oceanologica 33 (2): 162-175. https://doi.org/10.1016/j.actao.2007.10.008

Montagu G. 1804. Description of several marine animals found on the south coast of Devonshire. Transactions of the Linnean Society of London 7 (1): 61-85.

https://doi.org/10.1111/j.1096-3642.1804.tb00282.x

Morales-Zárate M.V., Zayas-Álvarez A., Salinas-Zavala C.A. \& Mejía-Rebollo A. 2016. Biocenosis de la comunidad bentónica en la Laguna Guerrero Negro, Baja California Sur, México: caracterización espacio-temporal. Latin American Journal of Aquatic Research 44: 726-741.

https://doi.org/10.3856/vol44-issue4-fulltext-8

Murina V.V. 1957. Abyssal sipunculids (genus Phascolion Thèel) of the northwestern part of the Pacific collected by Vitjaz expeditions in 1950-1955. Zoologicheskii Zhurnal 36: 1777-1791.

Murina V.V. 1967. Report on the sipunculid worms from the sublitoral zone of Cuba and the Gulf of Mexico. Zoologicheskii Zhurnal 54: 1329-1339.

Murina V.V. 1984. Ecology of Sipuncula. Marine Ecology Progress Series 17: 1-7. https://doi.org/10.3354/meps017001

Pallas P.S. 1774. Lumbricus. In: Spicilegia Zoologica. Lange, Berlin.

Quatrefages M.A. de. 1865. Annélides et géphyriens. In: Histoire naturelle des Annelés marins et d'Eau douce. Libraire Encyclopédique de Roret, Paris.

Available from https://www.biodiversitylibrary.org/page/52110858 [accessed 4 Mar. 2021].

Saiz-Salinas J.I. 1983. Redescripción de los antiguos Tipos de Sipuncúlidos (Sipuncula) descritos por el Prof. Jean-Louis-Armand de Quatrefages de Breau en 1865 y encontrados en las Colecciones de Laboratorio de los Gusanos del Museo Nacional de Historia Natural de Paris. Dissertation. Universidad del País Vaco, Bilbao, Spain.

Salazar-Vallejo S.I. 1983. Sipunculida del Pacífico: Generalidades, lista de especies y nuevo registro. BIOS 1: 30-34.

Schulze A., Cutler E.B. \& Giribet G. 2007. Phylogeny of sipunculan worms: a combined analysis of four gene regions and morphology. Molecular Phylogenetics and Evolution 42 (1): 171-192.

https://doi.org/10.1016/j.ympev.2006.06.012

Schulze A., Maiorova A., Timm L.E. \& Rice M.E. 2012. Sipunculan larvae and "cosmopolitan" species. Integrative and Comparative Biology 52 (4): 497-510. https://doi.org/10.1093/icb/ics082

Schulze A., Boyle M. \& Kawauchi G. 2019. Amphinomida/Sipuncula. In: Purschke G., Böggemann M. \& Westheide W. (eds) Handbook of Zoology, Annelida: Volume 1: Basal Groups and Pleistoannelida, Sedentaria I: 177-216. Walter De Gruyter GmbH, Berlin/Boston.

Selenka E. 1883. Die Sipunculiden, eine systematische Monographie. Reisen in Archipel Phillippinen von Dr. C. Semper. C.W. Kreidel, Wiesbaden. 
Silva-Morales I. 2020. Reinstatement of Phascolosoma (Phascolosoma) varians Keferstein, 1865 (Sipuncula: Phascolosomatidae) based on morphological and molecular data. PeerJ 8: e10238. https://doi.org/10.7717/peerj.10238

Silva-Morales I., López-Aquino M.J., Islas-Villanueva V., Ruiz-Escobar F. \& Bastida-Zavala J.R. 2019. Morphological and molecular differences between the Amphiamerican populations of Antillesoma (Stephen \& Edmonds, 1972) (Sipuncula: Antillesomatidae), with the description of a new species. Revista de Biología tropical 67: 101-109. https//doi.org/10.15517/RBT.V67IS5.38934

Sluiter C.P. 1902. Die Sipunculiden und Echiuriden der Siboga Expedition, nebst Zusammenstellung der ueberdies aus dem indischen Archipel bekannten Arten. Siboga Expeditie 25: 1-53. Available from https://www.biodiversitylibrary.org/page/2046852 [accessed 4 Mar. 2021].

Spongberg A.L. 2006. PCB concentrations in intertidal sipunculan (Phylum Sipuncula) marine worms from the Pacific coast of Costa Rica. Revista de Biología tropical 54: 27-33.

https//doi.org/10.15517/RBT.V54I1.26836

Staton J.L. 2003. Phylogenetic analysis of the mitochondrial cytochrome c oxidase subunit I gene from 13 sipunculan genera: intra- and interphylum relationships. Invertebrate Biology 122 (3): 252-264. https://doi.org/10.1111/j.1744-7410.2003.tb00089.x

Staton J. \& Rice M.E. 1999. Genetic differentiation despite teleplanic larval dispersal: allozyme variation in sipunculans of the Apionsoma misakianum species complex. Bulletin of Marine Science 65: 467-80.

Steinbeck J. \& Ricketts E.F. 1941. Sea of Cortez: A Leisurely Journal of Travel and Research. Viking Press, New York.

Stephen A.C. \& Edmonds S.J. 1972. The Phyla Sipuncula and Echiura. Trustees of the British Museum (Natural History), London.

Struck T.H., Schult N., Kusen T., Hickman E., Bleidorn C. \& McHugh D. 2007. Annelid phylogeny and the status of Sipuncula and Echiura. BMC Evolutionary Biology 7: e57.

https://doi.org/10.1186/1471-2148-7-57

Yupanqui W., Quipúzcoa L., Marquina R., Velazco F., Enriquez E. \& Gutiérrez D. 2007. Composición y distribución del macrobentos en la Ensenada de Sechura, Piura, Perú. Revista peruana de Biología 14: 75-85. https://doi.org/10.15381/rpb.v14i1.1763

Manuscript received: 10 March 2020

Manuscript accepted: 20 December 2020

Published on: 25 March 2021

Topic editor: Rudy Jocqué

Desk editor: Danny Eibye-Jacobsen

Printed versions of all papers are also deposited in the libraries of the institutes that are members of the EJT consortium: Muséum national d'histoire naturelle, Paris, France; Meise Botanic Garden, Belgium; Royal Museum for Central Africa, Tervuren, Belgium; Royal Belgian Institute of Natural Sciences, Brussels, Belgium; Natural History Museum of Denmark, Copenhagen, Denmark; Naturalis Biodiversity Center, Leiden, the Netherlands; Museo Nacional de Ciencias Naturales-CSIC, Madrid, Spain; Real Jardín Botánico de Madrid CSIC, Spain; Zoological Research Museum Alexander Koenig, Bonn, Germany; National Museum, Prague, Czech Republic. 


\section{Appendix}

\section{Commented list of all sipunculan species from the Tropical Eastern Pacific}

We found records of 53 taxa of sipunculans of which five names are similar to other nominal species, 25 records are considered questionable because the type locality and/or native distribution of the nominal species is far away from the TEP, two are new species and the rest are records of nominal species previously found in the TEP.

Phylum Sipuncula Rafinesque, 1814

Family Antillesomatidae Kawauchi, Sharma \& Giribet, 2012

Genus Antillesoma Stephen \& Edmonds, 1972

Antillesoma antillarum (Grube \& Örsted in Grube, 1858): 117-118, as Phascolosoma antillarum; type locality: Saint Croix, Virgin Islands. - Cutler et al. 1992: 156 (Conchal Beach, Brasilito Bay; Murcielagos Island, Gulf of Papagayo; Point Morales, Gulf of Nicoya; Point Judas; Mal País, Cabo Blanco; Sámara Beach, Costa Rica). — Dean 2001: 87-88 (Conchal Beach, Brasilito Bay; Point Morales, Gulf of Nicoya; Sámara Beach; Mal País; Cabo Blanco; Point Judas; Murcielagos Islands, Gulf of Papagayo; Rincón de Osa, Golfo Dulce, Costa Rica). - Spongberg 2006: 30, fig. 1b (Culebra Bay, Costa Rica). - Dean et al. 2010: 62 (Chatham Bay, Costa Rica). Questionable records in the TEP.

Antillesoma mexicanum Silva-Morales et al., 2019: 105-106, fig. 2 (Southern Mexican Pacific, intertidal and subtidal, $3 \mathrm{~m}$, in dead coral and pier piles).

Family Aspidosiphonidae Baird, 1868

Genus Aspidosiphon Diesing, 1851

Subgenus Aspidosiphon (Akrikos) Cutler \& Cutler, 1989

Aspidosiphon (Akrikos) albus Murina, 1967: 1330-1331, fig. 2, as Aspidosiphon albus; type locality: Cuba, 22 ${ }^{\circ} 56^{\prime} \mathrm{N}, 8^{\circ} 23^{\prime} \mathrm{W}, 14 \mathrm{~m}$. - Hermoso-Salazar et al. 2013: 331-332 (Wagner and Consag Basins, Gulf of California, Mexico, sandy loam bottom, 59-121 m). Questionable record in the TEP.

Aspidosiphon cf. albus in Salazar-Vallejo 1983: 32-33 (Manzanillo Bay, Colima, Mexico, 20-70 m, in muddy-sandy sediments).

Subgenus Aspidosiphon (Aspidosiphon) Diesing, 1851

Aspidosiphon (Aspidosiphon) elegans (Chamisso \& Eysenhardt, 1821): 351-352, pl. 24, fig. 5a-e, as Sternaspis elegans; type locality: Radack, Marshall Islands. — Fonseca \& Cortés 1988: 172-173, as A. elegans (Pacific of Costa Rica). - Dean 2001: 89 (Golfo Dulce, Costa Rica, in dead coral). — Dean et al. 2010: 63-64, as A. elegans (Chatham Bay, Point Ulloa and Wafer Bay, Cocos Island, Costa Rica). Questionable records in the TEP.

Aspidosiphon (Aspidosiphon) gosnoldi Cutler, 1981: 445-449, as Aspidosiphon gosnoldi; type locality: Eastern Florida, United States, USGS, 2930' N, 80²9' W, $32 \mathrm{~m}$ ). - Dean et al. 2010: 64, as A. gosnoldi (Chatham Bay, Wafer Bay, Manuelita Island and Point Ulloa, Cocos Island, Costa Rica, specimens removed from shell). Questionable record in the TEP.

Aspidosiphon (Aspidosiphon) gracilis schnehageni (Fischer, 1913): 99-100, pl. 30, figs 4-6, as Aspidosiphon schnehageni; type locality: Chile, in shell of Epitonium Röding, 1798. — Dean 2001: 89 (Gulf of Nicoya, Costa Rica, muddy sand). Questionable record in the TEP. 
Aspidosiphon (Aspidosiphon) misakiensis Ikeda, 1904: 41-43, pl. 1, fig. 9, pl. 3, figs 68-72, as Aspidosiphon misakiensis; type locality: Misaki, Japan, on rocky coast. — Dean et al. 2010: 64, as A. misakiensis (Silverado, Cocos Island, Costa Rica, subtidal calcareous rock, $11 \mathrm{~m}$ ). Questionable record in the TEP.

Aspidosiphon (Aspidosiphon) muelleri Diesing, 1851: 68, as Aspidosiphon muelleri; type locality: Palermo, Sicily, Italy). — Dean 2001: 89 (Gulf of Nicoya, Costa Rica, muddy sand). Questionable record in the TEP.

\section{Subgenus Aspidosiphon (Paraspidosiphon) (Stephen, 1965)}

Aspidosiphon (Paraspidosiphon) coyi Quatrefages, 1865: 608-609, as Aspidosiphon coyi; type locality: Indian Ocean. - Keferstein 1867: 50-53, pl. 6, figs 15-18, as Phascolosoma truncatum (probably Panama and Galapagos Islands, without specification by the author). Questionable record in the TEP.

Aspidosiphon (Paraspidosiphon) cutleri sp. nov. (this paper): Fig. 12A-F (Oaxaca, subtidal, 2 m, in dead coral).

Aspidosiphon (Paraspidosiphon) fischeri ten Broeke, 1925: 92-93, figs 21-22, as Aspidosiphon fischeri; type locality: Caracas Bay, Venezuela. — Dean et al. 2010: 65 (Chatham Bay, Ulloa Point, Manuelita Island, and Silverado, Cocos Island, Costa Rica, in calcareous rocks). Questionable record in the TEP.

Aspidosiphon (Paraspidosiphon) laevis Quatrefages, 1865: 609, pl. 20, figs 23-24, as Aspidosiphon laeve; type locality: probably Indian Ocean. - Cantera et al. 2003: 212, as A. laevis (in dead Pocillopora damicornis, Gorgona Island, Colombia). - Fonseca et al. 2005: 102 (Golfo Dulce, Costa Rica). - Dean et al. 2010: 65 (Chatham Bay, María Point, Ulloa Point, and Silverado, Cocos Island, Costa Rica, in calcareous rocks). Questionable records in the TEP.

Aspidosiphon (Paraspidosiphon) pastori sp. nov. (this paper): Fig. 13A-F (Guerrero and Oaxaca, Mexico, intertidal and subtidal, 7 m, in dead coral, sponge, epibionts of Spondylus limbatus).

Aspidosiphon (Paraspidosiphon) steenstrupii Diesing, 1859: 767, as Aspidosiphon steenstrupii; type locality: Saint Thomas, Virgin Islands. - Fonseca et al. 2005: 107 (Golfo Dulce, Costa Rica). Cantera et al. 2003: 212 (in dead Pocillopora damicornis, Gorgona Island, Colombia). Questionable records in the TEP.

Aspidosiphon sp. in Cantera et al. 2003: 212 (living Pocillopora damicornis, Gorgona Island, Colombia).

Family Golfingiidae Stephen \& Edmonds, 1972

Genus Golfingia Lankester, 1885

Golfingia sp. in Morales-Zárate et al. 2016: 741 (Guerrero Negro lagoon, Baja California Sur, Mexico).

Genus Nephasoma Pergament, 1940

Subgenus (Nephasoma) Pergament, 1940

Nephasoma (Nephasoma) eremita Sars, 1851. - Fisher 1952: 399-400, pl. 25, figs 1-3, as Golfingia elachea (Point Lobos, Espíritu Santo Island, near La Paz, Baja California Sur, Mexico). Questionable name. 
Nephasoma (Nephasoma) pellucidum pellucidum (Keferstein, 1865): 433, pl. 23, figs 26-27, as Phascolosoma pellucidum; type locality: Saint Thomas, Virgin Islands (0.6 m, in debris coral). Dean 2001: 87 (Puntarenas, Gulf of Nicoya; Playa Conchal, Brasilito Bay; Sándalo, Golfo Dulce, Costa Rica, intertidal zone, under boulders). Questionable record in the TEP.

Nephasoma sp. in Hermoso-Salazar et al. 2013: 329 (Wagner and Consag Basins, Gulf of California, Mexico, 150-162 m, sandy loam bottom).

Genus Onchnesoma Koren \& Danielssen, 1875

Onchnesoma magnibathum Cutler 1969: 71-76, as Onchnesoma magnibatha; type locality: NW Atlantic Ocean, 33⒌ $57^{\prime} \mathrm{N}, 65^{\circ} 47^{\prime} \mathrm{W}, 4795 \mathrm{~m}$ ). - Cutler \& Cutler 1980: 204-205 (Pacific of Costa Rica, Peru and Nicaragua, R/V Vema, Peru, 2270-3523 m). Questionable record in the TEP.

Onchnesoma steenstrupii steenstrupii Koren \& Danielssen, 1875: 133, pl. 15, figs 28-36; type locality: N Atlantic Ocean. - Hermoso-Salazar et al. 2013: 330 (Wagner and Consag Basins, Gulf of California, 128-185 m, sandy loam bottom). Questionable record in the TEP.

Genus Phascolion Théel, 1875

Subgenus Phascolion (Montuga) Gibbs, 1985

Phascolion (Montuga) pacificum Murina, 1957: 1777-1781, figs 2a-b, 3a-e, as Phascolion pacificum; type locality: Kuril Trench. — Cutler \& Cutler 1980: 194 (R/V Vema, Peru). Questionable record in the TEP.

\section{Subgenus Phascolion (Phascolion) Théel, 1875}

Phascolion (Phascolion) strombus (Montagu, 1804): 74-76, as Sipunculus strombus; type locality: S coast of Devonshire, UK. - Dean 2001: 87 (Gulf of Nicoya, 18 m, muddy sand, in an empty gastropod shell). Questionable record in the TEP.

Phascolion sp. in Hermoso-Salazar et al. 2013: 330-331 (Wagner and Consag Basins, Gulf of California, Mexico, 101-179 m, sandy loam bottom).

Genus Phascolopsis (Fisher, 1950)

Phascolopsis cf. gouldii (de Pourtalès, 1851). - Steinbeck \& Ricketts 1941: 345, as Phascolosoma gouldii (under boulders, Point Lobos, Espíritu Santo Island, Baja California Sur, Mexico).

Genus Themiste Gray, 1828

Subgenus Themiste (Themiste) Gray, 1828

Themiste (Themiste) hennahi Gray, 1828: 8, pl. 6, fig. 4-4a, as Themiste hennahi; type locality: Peru. - Fisher 1952: 411-415, pl. 30, fig. 1, pl. 30, pl. 31, as Dendrostomum zostericolum (Ensenada, Baja California, Mexico, among eelgrass roots; in gravel and sand under boulders; rocky tide flats, in sandy mud at lowest part of intertidal zone). - Fisher 1952: 419-422, pl. 35, as Dendrostomum lissum (San Carlos Bay, Baja California; Puerto Peñasco; Miramar Beach, Guaymas, Sonora, Mexico). - Brusca 1980: 126, as Themiste lissum (Gulf of California, Mexico). - Present paper (San Agustín Bay, Oaxaca, Mexico, inhabiting Porites).

Themiste sp. in Morales-Zárate et al. 2016: 741 (Guerrero Negro Lagoon, Baja California Sur, Mexico). 
Golfingiidae sp. in Hermoso-Salazar et al. 2013: 329-330 (Wagner and Consag Basins, Gulf of California, Mexico, 59-119 m, sandy loam bottom).

\author{
Family Phascolosomatidae Stephen \& Edmonds, 1972 \\ Genus Apionsoma Sluiter, 1902 \\ Subgenus Apionsoma (Apionsoma) Sluiter, 1902
}

Apionsoma (Apionsoma) hespera Chamberlin, 1920 comb. nov.: 31, as Phascolosoma hespera; type locality: Laguna Beach, California. - Steinbeck \& Ricketts 1941: 345, as Phascolosoma hesperum (abundant as commensals of tubes of Cerianthus, Cabo San Lucas, Baja California Sur, Mexico). Fisher 1952: 393-395, pl. 24, figs 1-5, as Golfingia hespera (Cabo San Lucas and S coast of Santa Rosalía, Baja California Sur, Mexico, inhabiting tubes of Cerianthus). — Brusca 1980: 125-126, as Golfingia hespera (Gulf of California, Mexico). - Amor 1975: 115-116 (Peru). [Phascolosoma hespera (Chamberlin, 1920) was previously regarded as a synonym of $A$. (A.) misakianum (Ikeda, 1904): 7-9, pl. 1, fig. 3, pl. 2, figs 30-33, as Phascolosoma misakianum,; type locality: Misaki, Japan.] Reinstatement of name and proposal of a new combination.

Apionsoma (Apionsoma) trichocephalus Sluiter, 1902: 42-44, pl. 4, figs 8-11, as Apionsoma trichocephalus; type locality: Philippines, $7^{\circ} 25^{\prime} \mathrm{S}, 113^{\circ} 16^{\prime} \mathrm{E}$, Siboga expedition, in gray mud. Cutler et al. 1992: 156, as Apionsoma trichocephala (Gulf of Nicoya, Costa Rica). - Dean 2001: 88 (Gulf of Nicoya, Costa Rica, in sandy mud). Questionable records in the TEP.

Apionsoma (Apionsoma) sp. in Hermoso-Salazar et al. 2013: 331 (Wagner and Consag Basins, Gulf of California, 88-217 m, sandy loam bottom).

Subgenus Apionsoma (Edmondsius) Gibbs \& Cutler, 1987

Apionsoma (Edmondsius) pectinatum (Keferstein, 1867): 47-48, as Phascolosoma pectinatum; type locality: Pacific of Panama. - Fisher, 1952: 386-388, pl. 22, as Siphonides rickettsi (Point Lobos, Espíritu Santo Island, Baja California Sur, Mexico). - Brusca 1980: 127, as Phascolosoma rickettsi (Gulf of California, Mexico). - Dean 2001: 88 (Herradura Bay, Gulf of Nicoya and Gulf of Papagayo, Costa Rica, in rocks).

Genus Phascolosoma Leuckart, 1828

Subgenus Phascolosoma (Phascolosoma) Leuckart, 1828

Phascolosoma (Phascolosoma) agassizii agassizii Keferstein, 1866: 218-219, as Phascolosoma agassizii; type locality: Mendocino, California. - Steinbeck \& Ricketts 1941: 345-346 (under boulders, intertidal, Point Lobos, Espíritu Santo Island, Baja California Sur). — Brusca \& Thompson 1977: 44, as P. agassizii (Cabo Pulmo reef, Baja California Sur, Mexico, in coral). — Brusca 1980: 126, as P. agassizii (Gulf of California, Mexico). - Dean et al. 2010: 62, as P. agassizii (Point Ulloa, Costa Rica, in calcareous rock).

Phascolosoma cf. agassizii in Steinbeck \& Ricketts, 1941: 346, as Physcosoma cf. agassizii (in debris of Pocillopora, Cabo Pulmo reef; Baja California Sur; under boulders, Puerto Escondido, Baja California Sur; in rocks, San Carlos Bay, Baja California Sur; under boulders, Puerto Refugio, Baja California, Mexico).

Phascolosoma (Phascolosoma) perlucens Baird, 1868: 90-91, pl. 10, fig. 2-2a, as Phascolosoma perlucens; type locality: Jamaica (coralline rocks). — Fisher 1952: 432-434, pl. 39, figs 4-7, as P. dentigerum (Cabo Pulmo reef, in Pocillopora, Baja California Sur; Puerto Escondido, San Carlos 
Bay, Baja California Sur; Puerto Refugio, Ángel de la Guarda Island, Gulf of California, Mexico; Panama Bay, Panama). - Brusca 1980: 127, as P. perlucens (Gulf of California, Mexico). Cutler et al. 1992: 154, as P. perlucens (Murcielagos Islands; Point Morales, Gulf of Nicoya; Wafer Bay, Cocos Island, Costa Rica). - Fonseca et al. 2005: 107 (Golfo Dulce, Costa Rica). - Dean 2001: 87 (Murcielagos Islands, Gulf of Papagayo, in sandstone, intertindal; Point Morales, Gulf of Nicoya, in sandstone, intertidal; Pacific Coast, Punta Judas, in hardened clay; Mal País, Cabo Blanco, in limestone; Wafer Bay, Cocos Island, under rocks, intertidal; Rincón de Osa, Golfo Dulce, between rocks, intertidal, Costa Rica). - Schulze et al. 2007: 186 (Puerto Peñasco, Sonora, Mexico). Spongberg 2006: 30, fig. 1c (sandflats, Cocosrocas, Gulf of Nicoya; Culebra Bay; Puerto Jiménez and E of Rincón, Golfo Dulce, Cost Rica). Questionable records in the TEP.

Phascolosoma (Phascolosoma) cf. perlucens Baird, 1868 in this paper: Fig. 6A-G (Southern Mexican Pacific, intertidal and subtidal 0-20 m, in dead coral, pier piles, in algae, sabelariid colony, mangrove roots, sand, epibionts of Pinctada mazatlantica, Pocillopora damicornis and Porites sp.). [Different lineage according to Kawauchi \& Giribet 2010.]

Phascolosoma (Phascolosoma) puntarenae Grube \& Örsted in Grube, 1858: 13; type locality: Puntarenas, Costa Rica. - Fisher 1952: 430-432, pl. 36, figs 1-2, pl. 37, figs 1-3, pl. 30, fig. 3 (Espíritu Santo Island, Baja California Sur; Miramar Beach, Guaymas, Sonora, Mexico; Panama Bay, Panama). - Brusca 1980: 127, as P. puntarena (Gulf of California, Mexico). - Cutler et al. 1992: 154-156, as P. nigrescens (Conchal Beach, Costa Rica). — Fonseca et al. 2005: 107 (Golfo Dulce, Costa Rica). - Dean et al. 2010: 63 (Ulloa Point and Chatham Bay, Cocos Island, Costa Rica in calcareous rock). - Dean 2001: 87 (Puntarenas, Gulf of Nicoya; Conchal Beach, Brasilito Bay; Sándalo, Golfo Dulce, Costa Rica, between rocks). [Phascolosoma (P.) puntarenae has been considered a synonym of $P$. (P.) nigrescens (Keferstein, 1865): 424, pl. 21, fig. 2, pl. 23, figs 14-15; type locality: Fiji.] Name reestablished in this paper.

Phascolosoma (Phascolosoma) scolops Selenka \& De Man in Selenka, 1883: 75-76, as Phascolosoma scolops; type locality: Philippines. - Dean et al. 2010: 63, as P. scolops (Silverado, Costa Rica). Questionable record in the TEP.

Phascolosoma sp. in Dean et al. 2010: 63 (Chatham Bay and Point Ulloa, Cocos Island and Silverado, Costa Rica).

Phascolosoma sp. in Hermoso-Salazar et al. 2013: 331 (Wagner and Consag Basins, Gulf of California, Mexico, $113.1 \mathrm{~m}$, sandy loam bottom).

Family Siphonosomatidae Kawauchi, Sharma \& Giribet, 2012

Genus Siphonosoma Spengel, 1912

Siphonosoma cumanense (Keferstein, 1867): 53-55, pl. 6, figs 19-21, as Phascolosoma cumanense; type locality: Cumaná, Venezuela. - Dean et al. 2010: 61-62 (Chatham Bay, Costa Rica, 29.9 m, sandy bottom). Questionable record in the TEP.

Siphonosoma cf. cumanense in this paper: Fig. 3A-D (Santa Cruz Beach, Huatulco, Oaxaca, in sand, $3 \mathrm{~m})$. Questionable record in the TEP.

Siphonosoma vastum (Selenka \& Bülow in Selenka, 1883): 103-104, pl. 12, fig. 171, pl. 13, fig. 179, as Sipunculus vastus; type locality: Jaluit, Marshall Islands (without details). — Cutler et al. 1992: 154 (Isla del Caño, Costa Rica, under boulders and in debris coral). — Dean 2001: 86-87 (same data as preceding). Questionable records in the TEP. 
Siphonosoma cf. vastum in this paper: Fig. 4A-H (San Agustín Bay, Huatulco, Oaxaca, Mexico, between rock and sand, $3 \mathrm{~m}$ ).

Family Sipunculidae Rafinesque, 1814

Genus Sipunculus Linnaeus, 1766

Subgenus Sipunculus (Sipunculus) E. Cutler \& Cutler, 1985

Sipunculus (Sipunculus) cf. polymyotus in this paper: Figs 1A-E, 2A-D (Boquilla Beach, Puerto Ángel, sandy substrate, $5 \mathrm{~m}$ ).

Sipunculus (Sipunculus) natans Fisher 1954: 238-240, figs 1-2, type locality: Santa Inés Bay, Baja California Sur, Mexico.

Sipunculus (Sipunculus) nudus Linnaeus, 1766: 1078; type locality: European Ocean. — Steinbeck \& Ricketts 1941: 346 (in mud, El Mogote, Baja California Sur; in sand, Bahía de los Ángeles, Baja California, Mexico). — Fisher 1952: 376-377, pl. 18 (Guaymas, Sonora, lagoon at Miramar Beach, 6 mi. from Ensenada; El Mogote, near La Paz, Baja California Sur; Estero de Punta Banda, Baja California, Mexico). - Brusca 1980: 125 (Gulf of California). - Cutler et al. 1992: 153 (Point Morales, Gulf of Nicoya, Costa Rica, intertidal to $12 \mathrm{~m}$ in mud and sand). - Dean 2001: 86 (Puntarenas, Costa Rica, intertidal to $18 \mathrm{~m}$, in mud and sand). - Schulze et al. 2007: 186 (Taboguilla Island, off Panama City, Panama). - Spongberg 2006: 30, fig. 1d (sandflats, Gulf of Nicoya, Costa Rica). - Melwani \& Kim 2008: 171 (sediments outside hydrothermal vents, Concepción Bay, Baja California Sur, Mexico). - Hermoso-Salazar et al. 2013: 328-329 (Wagner and Consag Basins, Gulf of California, 59-162 m, sandy loam bottom). - Berrú \& Berrú 2013: 245-252 (North of Peru). Questionable records in the TEP.

Sipunculus (Sipunculus) phalloides phalloides (Pallas, 1774): 12-15, pl. 1, as Lumbricus phalloides; type locality: coast of Granada. - Fisher 1947: 358-360, as Sipunculus galapagensis (Galapagos Islands, in fish stomach). - Cutler et al. 1992: 153-154 (Herradura Bay, Gulf of Nicoya, Costa Rica, 10 m, under debris of coral and in sand). - Dean 2001: 86 (Puntarenas, Gulf of Nicoya; Conchal Beach, Brasilito Bay, Costa Rica, in fine sand). Questionable records in the TEP.

Sipunculus sp. in Cantera et al. 2003: 212 (in dead and live Pocillopora damicornis, Gorgona Island, Colombia).

Sipunculus sp. in Fonseca et al. 2005: 106 (Golfo Dulce, Costa Rica).

Sipunculidae sp. in Yupanqui et al. 2007: 79 (Ensenada de Sechura, Piura, Peru).

Genus Xenosiphon Fisher, 1947

Xenosiphon branchiatus (Fischer, 1895): 3, pl. 1, figs 1-1a, 2, as Sipunculus mundanus var. branchiatus; type locality: Esmeraldas, Ecuador. - Fisher 1947: 360-363, as Xenosiphon branchiatum (from La Paz, Baja California Sur to Panama). - Fisher 1952: 377-380, pl. 19, as X. branchiatum (La Paz, Baja California Sur; Panama, Hassler Expedition). - Brusca 1980: 125, as X. branchiatum (Gulf of California). - Cutler et al. 1992: 154 (Curú Beach, Gulf of Nicoya; Tamarindo Beach, Costa Rica, in fine sand). - Dean 2001: 86 (Conchal Beach, Brasilito Bay; Curú Beach, Gulf of Nicoya; Tamarindo Beach, Tamarindo Bay, Costa Rica, in fine sand). - Schulze et al. 2007: 186 (Tamarindo Beach, Costa Rica). 